\title{
Carbon and nutrient mixed layer dynamics in the Norwegian Sea
}

\author{
H. S. Findlay ${ }^{1, *}$, T. Tyrrell ${ }^{1}$, R. G. J. Bellerby ${ }^{2,3}$, A. Merico ${ }^{4}$, and I. Skjelvan ${ }^{2,3}$ \\ ${ }^{1}$ National Oceanography Centre, Southampton, European Way, Southampton, UK \\ ${ }^{2}$ Bjerknes Centre for Climate Research, University of Bergen, Allegaten 55, 5007, Bergen, Norway \\ ${ }^{3}$ Geophysical Institute, University of Bergen, Allegaten 70, 5007, Bergen, Norway \\ ${ }^{4}$ Institute for Coastal Research, Geesthacht, Germany \\ *now at: Plymouth Marine Laboratory, Prospect Place, The Hoe, Plymouth, PL1 3DU, UK
}

Received: 24 August 2007 - Published in Biogeosciences Discuss.: 14 September 2007

Revised: 6 August 2008 - Accepted: 2 September 2008 - Published: 15 October 2008

\begin{abstract}
A coupled carbon-ecosystem model is compared to recent data from Ocean Weather Station $\mathrm{M}\left(66^{\circ} \mathrm{N}, 02^{\circ} \mathrm{E}\right)$ and used as a tool to investigate nutrient and carbon processes within the Norwegian Sea. Nitrate is consumed by phytoplankton in the surface layers over the summer; however the data show that silicate does not become rapidly limiting for diatoms, in contrast to the model prediction and in contrast to data from other temperate locations. The model estimates atmosphere-ocean $\mathrm{CO}_{2}$ flux to be $37 \mathrm{~g} \mathrm{C} \mathrm{m}^{-2} \mathrm{yr}^{-1}$. The seasonal cycle of the carbonate system at OWS M resembles the cycles suggested by data from other high-latitude ocean locations. The seasonal cycles of calcite saturation state and $\left[\mathrm{CO}_{3}^{2-}\right]$ are similar in the model and in data at OWS M: values range from $\sim 3$ and $\sim 120 \mu \mathrm{mol} \mathrm{kg}^{-1}$ respectively in winter, to $\sim 4$ and $\sim 170 \mu \mathrm{mol} \mathrm{kg}^{-1}$ respectively in summer. The model and data provide further evidence (supporting previous modelling work) that the summer is a time of high saturation state within the annual cycle at high-latitude locations. This is also the time of year that coccolithophore blooms occur at high latitudes.
\end{abstract}

\section{Introduction}

The Norwegian Sea (Fig. 1) is an important high latitude region for processes including uptake and sequestration of $\mathrm{CO}_{2}$, primary production and large-scale ocean mixing. As with many other high latitude locations the mixed layer depth undergoes large seasonal fluctuations forcing seasonal dynamics of biology and chemistry in the upper ocean (Nilsen and Falck, 2006). High concentrations of nutrients in winter (nitrate $>12 \mu \mathrm{mol} \mathrm{L}^{-1}$, phosphate $>0.9 \mu \mathrm{mol} \mathrm{L}^{-1}$ and silicate $>5.5 \mu \mathrm{mol} \mathrm{L}^{-1}$, Dale et al., 1999) are reduced to low

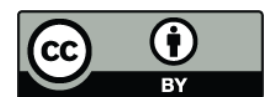

Correspondence to: H. S. Findlay (hefi@pml.ac.uk) levels in the surface layer by consumption during spring and summer. Interannual variations in observations give a range of nitrate summer concentrations between near $0 \mu \mathrm{mol} \mathrm{L}^{-1}$ and $2 \mu \mathrm{mol} \mathrm{L}^{-1}$ (Kohly, 1998; Haupt et al., 1999, Dale et al., 1999). The lack of full depletion of nitrate in summer at both OWS $\mathrm{M}$ and at $\left(60^{\circ} \mathrm{N}, 20^{\circ} \mathrm{W}\right)$ in the North Atlantic, compared to other temperate sites (e.g. NABE, $47^{\circ} \mathrm{N}, 20^{\circ} \mathrm{W}$ ), has been the subject of much speculation and two main hypotheses have been put forward to explain this phenomenon: 1) diatoms are present in low numbers and are limited by rapid consumption of silicate and hence do not bloom to the same magnitude as other areas (Dale et al., 1999); 2) large populations of micro-zooplankton grazers rapidly consume the other phytoplankton and prevent them from proliferating sufficiently to exhaust nitrate (Taylor et al., 1993; Peinert et al., 1989).

The eastern Bering Sea is another high-latitude site that has been used to investigate the associated dynamics of plankton and carbonate systems. A detailed understanding of how plankton and the carbonate system interact with each other in the real ocean is of interest for predicting how the ocean will respond to ongoing and future ocean acidification. Merico et al. (2006)'s model study assessed the possible links between success of the coccolithophore Emiliania huxleyi in the natural environment and the ambient values of carbonate ion concentration ( $\left[\mathrm{CO}_{3}^{2-}\right]$ ) following an earlier investigation addressing which environmental conditions may have contributed to the large $E$. huxleyi blooms in the eastern Bering Sea from 1996 to 2000 (Merico et al., 2004). Although the model calculated only minor interannual changes in calcite saturation state $\left(\Omega_{\mathrm{cal}}\right)$, which were not thought to have caused the interannual differences in patterns of $E$. huxleyi, there did appear to be a possible link between seasonal variations in $\Omega_{\text {cal }}$ and E. huxleyi success (Fig. 5 in Merico et al., 2006). They predicted a sharp rise in $\left[\mathrm{CO}_{3}^{2-}\right]$ and $\Omega_{\text {cal }}$ as a result of the spring blooms, leading to higher values in summer than in winter. Although $\left[\mathrm{CO}_{3}^{2-}\right], \Omega_{\mathrm{cal}}, p \mathrm{CO}_{2}$, etc. can

Published by Copernicus Publications on behalf of the European Geosciences Union. 


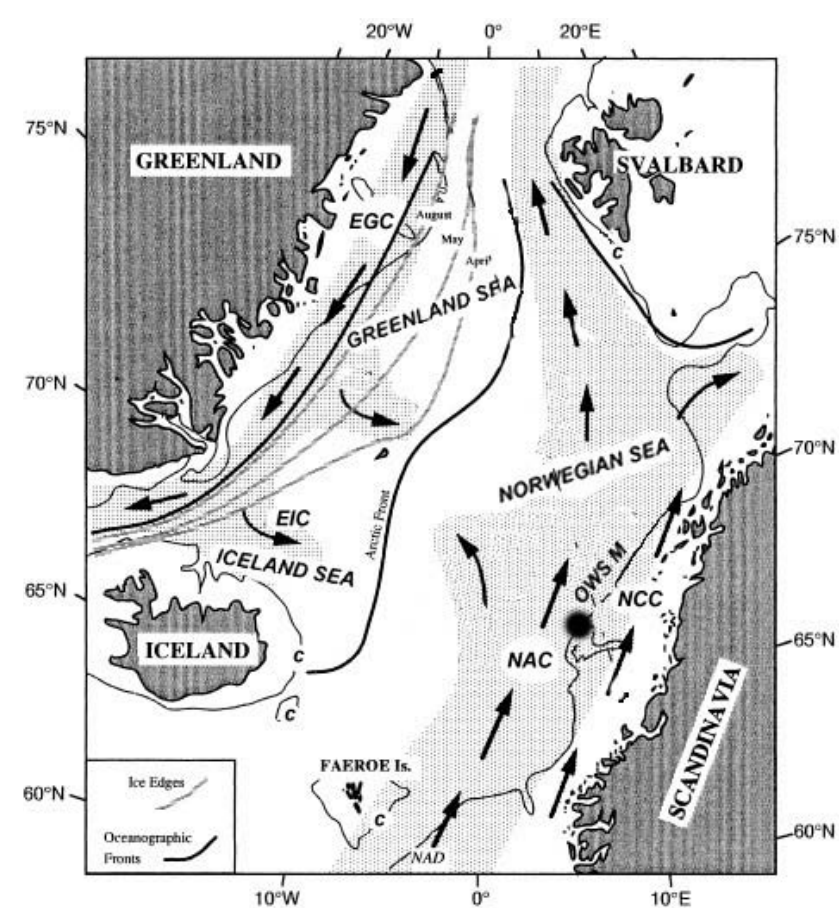

Fig. 1. Map of the Nordic Seas including major surface currents and Ocean Weather Station M (OWS M) at $66^{\circ} \mathrm{N}, 02^{\circ}$ E. Major oceanic fronts and approximate ice edges are also indicated and the continental shelf is marked by the c contour. EGC = East Greenland Current, EIC = East Icelandic Current, NAD = North Atlantic Drift, $\mathrm{NAC}=$ Norwegian Atlantic Current, $\mathrm{NCC}=$ Norwegian Coastal Current. Adapted from Andruleit (2000).

be calculated from total dissolved inorganic carbon $\left(\mathrm{C}_{\mathrm{T}}\right)$ and total alkalinity $\left(\mathrm{A}_{\mathrm{T}}\right)$, very little data were available from the eastern Bering Sea to validate and test these hypotheses. The presence of a time series site in the Norwegian Sea (Ocean Weather Station M (OWS M) at $66^{\circ} \mathrm{N}, 02^{\circ}$ E, Fig. 1) makes it ideal for further investigating the interactions between phytoplankton and the cycling of carbon and nutrients, which we carry out here using both data and modelling.

Seasonal fluctuations in $\mathrm{C}_{\mathrm{T}}$ result from a combination of removal by photosynthesis and addition from respiration, mixing and ingassing from the atmosphere (Skjelvan et al., 2005). The process of biological precipitation of calcium carbonate $\left(\mathrm{CaCO}_{3}\right)$ by calcifying organisms such as coccolithophores additionally impacts on the $\mathrm{C}_{\mathrm{T}}$ dynamics (Najjar, 1992), although the biogeochemical impacts of coccolithophores are not considered in any detail in this paper. Coccolithophores are present in the Norwegian Sea in low numbers during winter and spring with densities increasing in early summer (June) after the diatom bloom (Andruleit, 1997); with peaks up to $3 \times 10^{6}$ coccospheres $\mathrm{L}^{-1}$ (Baumann et al., 2000). The seasonal succession of phytoplankton could play an important role in determining the cycling of carbon and nutrients.

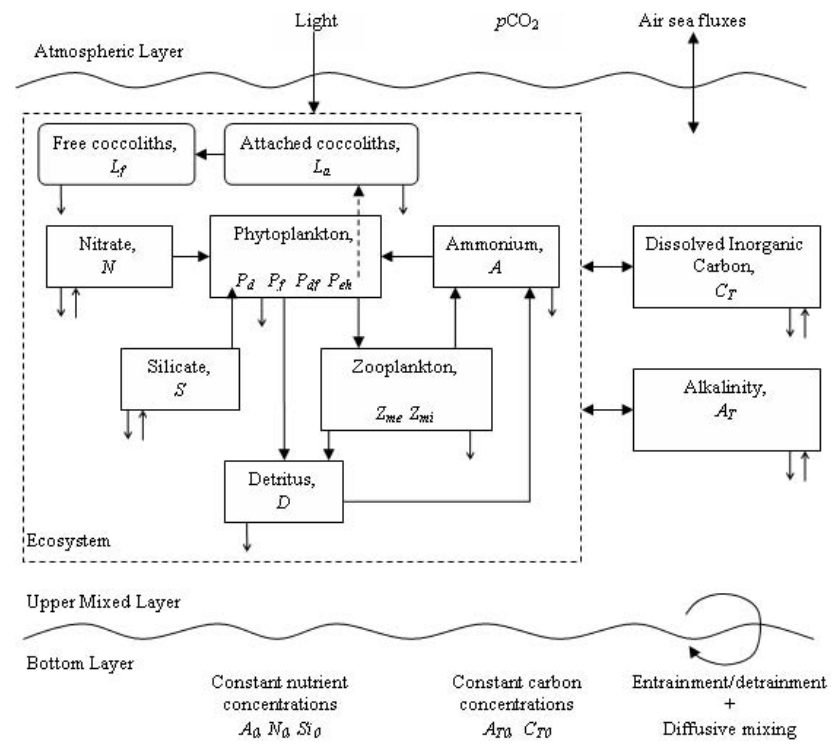

Fig. 2. Physical structure of the model with main biological and chemical components. Arrows represent exchange of materials. Open arrows indicate the material flowing between the mixed layer and bottom layer. The arrow from E.huxleyi $\left(P_{e h}\right)$ to attached coccoliths $\left(L_{a}\right)$ is dashed indicating that attached coccoliths are produced proportionately to the E.huxleyi concentration rather than with a real flow of material between these two compartments. Note that mesozooplankton $\left(Z_{m e}\right)$ also grazes on microzooplankton $\left(Z_{m i}\right)$. See text for more details. (Adapted from Merico et al., 2006).

This study aims to use an adaptation of Merico et al. (2006)'s model as a tool to investigate nutrient and carbonate system dynamics in the Norwegian Sea. Specifically, we address the controls on nitrate and silicate consumption rates over the summer and the seasonal patterns of the carbonate parameters. It is now widely accepted that biology strongly drives sea-surface $\mathrm{C}_{\mathrm{T}}$ and $p \mathrm{CO}_{2}$ at high latitudes, following landmark studies more than a decade ago (e.g. Takahashi et al., 1993; Garcon et al., 1992). Here we seek to demonstrate that biology also strongly drives the seasonal cycles of $\left[\mathrm{CO}_{3}^{2-}\right]$ and $\Omega_{\mathrm{cal}}$, and that they are driven to high values in summer. We do not possess concurrent coccolithophore counts from OWS M. Nevertheless, we assess the hypothesis that coccolithophore success occurs at times of high $\Omega_{\text {cal }}$ by comparing what is known more generally about the timing of coccolithophore blooms at high-latitudes against our result of high summer $\Omega_{\text {cal }}$.

\section{Methods}

\subsection{Model description}

Merico et al. (2006)'s two-layer, time-dependent, coupled biological-physical-carbon model is adapted here to 
Table 1. Parameters of the standard model compared to other models ( ${ }^{\mathrm{a}}$ Merico et al., 2004; ${ }^{\mathrm{b}}$ Evans and Parslow, 1985; ${ }^{\mathrm{c}}$ Fasham et al., 1990; dTaylor et al., 1993).

\begin{tabular}{|c|c|c|c|c|c|c|c|}
\hline Parameter & Symbol & Units & ${\mathrm{MBS} 04^{\mathrm{a}}}$ & $\mathrm{EP}^{\mathrm{b}} 5^{\mathrm{b}}$ & $\mathrm{F} 90^{\mathrm{c}}$ & $\mathrm{T}^{\mathrm{d}}{ }^{\mathrm{d}}$ & Current \\
\hline \multicolumn{8}{|l|}{ Diatoms $\left(P_{d}\right)$} \\
\hline Maximum growth rate at $0^{\circ} \mathrm{C}$ & $\mu_{0, d}$ & day $^{-1}$ & 1.2 & & 2.9 & 0.9 & 1.3 \\
\hline Minimum sinking speed & $v_{d}$ & $\mathrm{~m}$ day $^{-1}$ & 0.5 & & & & 0.5 \\
\hline Mortality rate & $m_{d}$ & day $^{-1}$ & 0.08 & & & & 0.08 \\
\hline Light saturation constant & $I_{s, d}$ & $\mathrm{~W} \mathrm{~m}^{-2}$ & 15 & & & & 15 \\
\hline Nitrate half-saturation constant & $N_{h, d}$ & $\mathrm{mmol} \mathrm{m}^{-3}$ & 1.5 & & 0.5 & 0.3 & 1.5 \\
\hline Ammonium half-saturation constant & $A_{h, d}$ & $\mathrm{mmol} \mathrm{m}^{-3}$ & 0.05 & & & 0.005 & 0.1 \\
\hline Silicate half-saturation constant & $S_{h}$ & $\mathrm{mmol} \mathrm{m}^{-3}$ & 3.5 & & & 0.3 & 3.5 \\
\hline \multicolumn{8}{|l|}{ Flagellates $\left(P_{f}\right)$} \\
\hline Maximum growth rate at $0^{\circ} \mathrm{C}$ & $\mu_{0, f}$ & day $^{-1}$ & 0.65 & & & & 0.6 \\
\hline Mortality rate & $m_{f}$ & day $^{-1}$ & 0.08 & & & & 0.1 \\
\hline Light saturation constant & $I_{s, f}$ & $\mathrm{Wm}^{-2}$ & 15 & & & & 15 \\
\hline Nitrate half-saturation constant & $N_{h, f}$ & $\mathrm{mmol} \mathrm{m}^{-3}$ & 1.5 & & & & 1.5 \\
\hline Ammonium half-saturation constant & $A_{h, f}$ & $\mathrm{mmol} \mathrm{m}^{-3}$ & 0.05 & & & & 0.1 \\
\hline \multicolumn{8}{|l|}{ Dinoflagellates $\left(P_{d f}\right)$} \\
\hline Maximum growth rate at $0^{\circ} \mathrm{C}$ & $\mu_{0, d f}$ & day $^{-1}$ & 0.6 & & & & 0.4 \\
\hline Mortality rate & $m_{d f}$ & day $^{-1}$ & 0.08 & & & & 0.12 \\
\hline Light saturation constant & $I_{s, d f}$ & $\mathrm{Wm}^{-2}$ & 15 & & & & 15 \\
\hline Nitrate half-saturation constant & $N_{h, d f}$ & $\mathrm{mmol} \mathrm{m}^{-3}$ & 1.5 & & & & 1.5 \\
\hline Ammonium half-saturation constant & $A_{h, d f}$ & $\mathrm{mmol} \mathrm{m}^{-3}$ & 0.05 & & & & 0.1 \\
\hline \multicolumn{8}{|l|}{ E. huxleyi $\left(P_{e h}\right)$} \\
\hline Maximum growth rate at $0^{\circ} \mathrm{C}$ & $\mu_{0, e h}$ & day $^{-1}$ & 1.15 & & & & 0.5 \\
\hline Mortality rate & $m_{e h}$ & day $^{-1}$ & 0.08 & & & & 0.08 \\
\hline Light saturation constant & $I_{S, e h}$ & $\mathrm{Wm}^{-2}$ & 45 & & & & 45 \\
\hline Nitrate half-saturation constant & $N_{h, e h}$ & $\mathrm{mmol} \mathrm{m}^{-3}$ & 1.5 & & 0.5 & 0.3 & 1.5 \\
\hline Ammonium half-saturation constant & $A_{h, e h}$ & $\mathrm{mmol} \mathrm{m}^{-3}$ & 0.05 & & & 0.005 & 0.1 \\
\hline \multicolumn{8}{|l|}{ Nitrate $(N)$} \\
\hline Deep concentration & $N_{0}$ & $\mathrm{mmol} \mathrm{m}^{-3}$ & 20 & 10 & & 10 & 12 \\
\hline Nitrification rate & $\Omega$ & day $^{-1}$ & 0.05 & & & & 0.05 \\
\hline \multicolumn{8}{|l|}{ Silicate $(S)$} \\
\hline Deep concentration & $S_{0}$ & $\mathrm{mmol} \mathrm{m}^{-3}$ & 35 & & & 6 & 5 \\
\hline \multicolumn{8}{|l|}{ Microzooplankton $\left(Z_{m i}\right)$} \\
\hline Assimilation efficiency $(\mathrm{S}<3 \mathrm{uM})$ & $B_{e h, m i}, B_{f, m i}, B_{d, m i}$ & & $0.75,0.75,0.75$ & 0.5 & 0.75 & & $0.75,0.75,0.75$ \\
\hline Assimilation efficiency $(\mathrm{S}>3 \mathrm{uM})$ & $B_{e h, m i}, B_{f, m i}, B_{d, m i}$ & & $0.75,0.75,0.75$ & & & & $0.75,0.75,0.75$ \\
\hline Grazing preferences $(\mathrm{S}<3 \mathrm{uM})$ & $P_{e h, m i}, P_{f, m i}, P_{d, m i}$ & & $0.33,0.33,0.33$ & & & & $0.2,0.6,0.2$ \\
\hline Grazing preferences $(\mathrm{S}>3 \mathrm{uM})$ & $P_{e h, m i}, P_{f, m i}, P_{d, m i}$ & & $0.5,0.5,0.0$ & & & & $0.3,0.6,0.1$ \\
\hline Max. ingestion rates $(\mathrm{S}<3 \mathrm{uM})$ & $g_{e h, m i}, g_{f, m i}, g_{d, m i}$ & day $^{-1}$ & $0.175,0.7,0.7$ & 1 & & & $0.7,0.7,0.7$ \\
\hline Max. ingestion rates $(\mathrm{S}>3 \mathrm{uM})$ & $g_{e h, m i}, g_{f, m i}, g_{d, m i}$ & day $^{-1}$ & $0.7,0.7,0.0$ & & 1 & & $0.7,0.7,0.7$ \\
\hline Grazing half-saturation constant & $Z_{h, m i}$ & $\mathrm{mmol} \mathrm{m}^{-3}$ & 1 & 1 & & & 1 \\
\hline Mortality rate & $m_{m i}$ & day $^{-1}\left(\mathrm{mmol} \mathrm{m}^{-3}\right)^{-1}$ & 0.05 & & 0.05 & & 0.05 \\
\hline Excretion rate & $e_{m i}$ & day $^{-1}$ & 0.025 & & 0.1 & & 0.025 \\
\hline Fraction of mort going to Ammonia & $\delta_{m i}$ & day $^{-1}$ & 0.1 & & 0.75 & & 0.1 \\
\hline \multicolumn{8}{|l|}{ Mesozooplankton $\left(Z_{m e}\right)$} \\
\hline Assimilation efficiency & $B_{d, m e}, B_{m i, m e}, B_{d f, m e}$ & & $0.75,0.75,0.75$ & & & & $0.75,0.75,0.75$ \\
\hline Grazing preferences & $P_{d, m e}, P_{m i, m e}, P_{d f, m e}$ & & $0.33,0.33,0.33$ & & & & $0.33,0.33,0.33$ \\
\hline Max. ingestion rate & $g_{d, m e}, g_{m i, m e}, g_{d f, m e}$ & $\mathrm{day}^{-1}$ & $0.7,0.7,0.7$ & & & & $0.7,0.7,0.7$ \\
\hline Grazing half-saturation constant & $Z_{h, m e}$ & $\mathrm{mmol} \mathrm{m}^{-3}$ & 1 & & & & 1 \\
\hline Mortality rate & $m_{m e}$ & day $^{-1}\left(\mathrm{mmol} \mathrm{m}^{-3}\right)^{-1}$ & 0.2 & & & & 0.05 \\
\hline Excretion rate & $e_{m e}$ & $\mathrm{day}^{-1}$ & 0.1 & & & & 0.1 \\
\hline Fraction of mort going to Ammonia & $\delta_{m e}$ & & 0.1 & & & & 0.1 \\
\hline \multicolumn{8}{|l|}{ Detritus $(D)$} \\
\hline Sinking speed & $V_{D}$ & $\mathrm{~m}_{\text {day }}{ }^{-1}$ & 0.4 & & $1-10$ & & 0.4 \\
\hline Breakdown rate & $m_{D}$ & day $^{-1}$ & 0.05 & & 0.05 & & 0.05 \\
\hline Cross-thermocline mixing rate & $k$ & $\mathrm{~m}_{\text {day }}{ }^{-1}$ & 0.01 & 3 & 0.1 & 0.2 & 0.2 \\
\hline Cloud cover & & & PAR data & 0.9 & 0.4 & & 0.75 \\
\hline \multicolumn{8}{|l|}{ Coccoliths as of Merico et al. (2004) } \\
\hline \multicolumn{8}{|l|}{ Carbonate system $\left(\mathrm{C}_{\mathrm{T}}, \mathrm{A}_{\mathrm{T}}\right)$} \\
\hline $\mathrm{C}_{T}$ deep concentration & $C_{T 0}$ & $\mu \mathrm{mol} \mathrm{kg}^{-1}$ & 2100 & & & & 2140 \\
\hline $\mathrm{A}_{T}$ deep concentration & $A_{T 0}$ & $\mu \mathrm{Eq} \mathrm{kg}^{-1}$ & 2250 & & & & 2320 \\
\hline Atmospheric $p \mathrm{CO}_{2}$ & $p \mathrm{CO}_{2 \text { (air) }}$ & $\mu \mathrm{atm}$ & 345 & & & & 377 \\
\hline
\end{tabular}


Table 2. Coccolithophore blooms occur later in the season than diatom spring blooms.

\begin{tabular}{lll}
\hline Location & Peak time for coccolithophore blooms & Reference \\
\hline Sub-arctic Northern Hemisphere $\left(40^{\circ} \mathrm{N}-70^{\circ} \mathrm{N}\right)$ & Jun-Jul-Aug & Brown and Yoder, 1994a \\
Sub-arctic North Atlantic $\left(40^{\circ} \mathrm{W}-11^{\circ} \mathrm{W}, 51^{\circ} \mathrm{N}-66^{\circ} \mathrm{N}\right)$ & Jun & Raitsos et al., 2006 \\
Western North Atlantic $\left(75^{\circ} \mathrm{W}-40^{\circ} \mathrm{W}, 40^{\circ} \mathrm{N}-60^{\circ} \mathrm{N}\right)$ & Aug & Brown and Yoder, 1994b \\
Eastern Bering Sea & Jul-Oct & Merico et al., 2004 \\
Northern North Sea & Jun and Jul & Holligan et al., 1993b \\
Barents Sea & Aug & Smyth et al., 2004 \\
Patagonian Shelf & Dec & http://cics.umd.edu/ $\sim$ chrisb/ehux_www.html \\
\hline
\end{tabular}
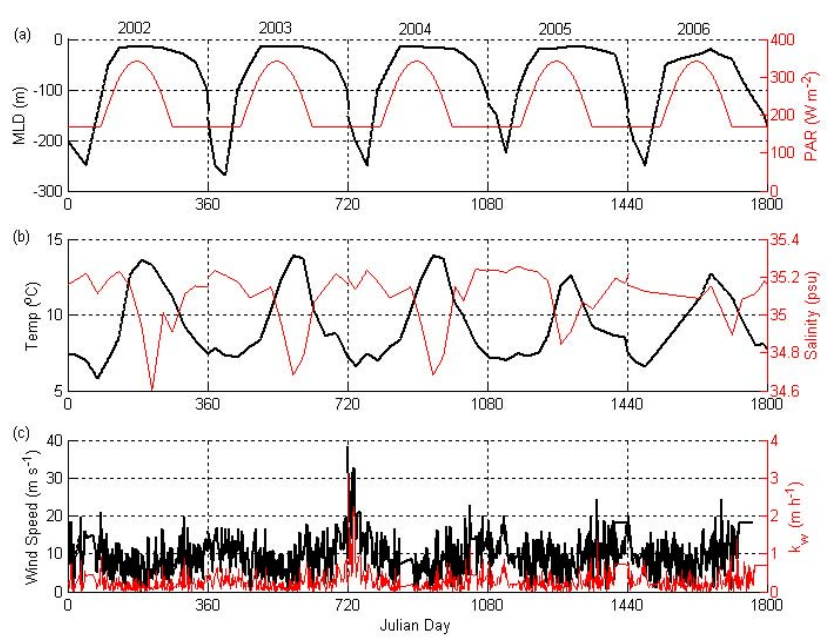

Fig. 3. Physical data from OWS M which is used to force the model over each year, 2002 to 2006. (a) MLD (m) (thick line) and daily average light available for phytoplankton at the sea surface $\left(\mathrm{W} \mathrm{m}^{-2}\right)$ (thin line), (b) sea surface temperature $\left({ }^{\circ} \mathrm{C}\right)$ (thick line) and sea surface salinity (psu) (thin line), and (c) wind speed $\left(\mathrm{m} \mathrm{s}^{-1}\right)$ (thick line) and gas transfer velocity $\left(h_{w}\right),\left(\mathrm{m} \mathrm{hr}^{-1}\right)$ (thin line).

represent the Norwegian Sea, with specific reference to the location of OWS M. The main adaptations made relate to the physical conditions (i.e. the forcing conditions) and the parameterisation of the ecosystem values. They are described in more detail below and in Table 1 .

The model is formulated as a bi-layer ocean system consisting of an upper, biologically active mixed layer (down to a seasonal thermocline), which contains phytoplankton, zooplankton and a limited amount of nutrients and chemical constituents; and a lower layer, containing no biology, but a source of nutrients and chemical constituents. The model also incorporates an atmospheric layer, with which air-sea fluxes of carbon dioxide can take place depending on the $\mathrm{CO}_{2}$ partial pressure differences between the atmosphere and the surface water (Fig. 2).

The system of ordinary differential equations is solved numerically using a Fourth-order Runge-Kutta method with a time step of one hour and was run over a period of four years to allow the state variables to reach repeatable seasonal cycles and thus minimise the dependency of the results on the initial conditions. For the state variable equations are readers are referred to Appendix A in Merico et al. (2006).

\subsubsection{The physical system}

The two-layer water column model used here is influenced simply by vertical advection and does not include any horizontal advection. This approximation, as this study will demonstrate, is suitable for assessing average annual dynamics as the location of OWS M encompasses the North Atlantic inflow, which is not thought to vary greatly through the seasons (Oliver and Heywood, 2003; Orvik and Skagseth, 2003). However it may not be appropriate for smaller scale interpretations of individual events within a year period because of incursions of coastal water.

The biological activity was considered to take place in the upper mixed layer, while in the bottom layer, nutrient concentrations (nitrate $\left(\mathrm{N}_{0}\right)$, silicate $\left(\mathrm{Si}_{0}\right)$ and ammonium $\left(\mathrm{A}_{0}\right)$ ) and carbon state variables $\left(\mathrm{C}_{\mathrm{T} 0}\right.$ and $\left.\mathrm{A}_{\mathrm{T} 0}\right)$ were kept constant throughout the year. Nutrients were supplied to the upper layer by entrainment or diffusive mixing across the interface using the same method of Fasham (1993).

The model was forced with a variable mixed layer depth, originally based on monthly Levitus climatologies (WOA98) at the location of OWS M, but linearly interpolated over time for each annual cycle using density data at OWS M for the period 2002-2006. Annual sea surface PAR was calculated using astronomical formulae (taking into account latitude, daily sinusoidal variation in radiation and a fixed cloud cover parameter). This does not capture the short-term changes in cloud cover and mixing events that occur in natural systems and therefore represents approximate values for each annual cycle. The light limited growth for each phytoplankton group was determined using a Steele's function, which includes the potential for saturation and inhibition of phytoplankton growth at high light levels. Initial investigations revealed that flagellate populations reached unrealistically high abundances when a simple Michaelis-Menten function for light limited growth was used. The effect of sea surface temperature (SST) on phytoplankton growth was simulated 
using Eppley's formulation (Eppley, 1972) and both sea surface salinity (SSS) and SST were used within the carbon system (Sect. 2.1.3). Values were taken from OWS M averaged monthly data and linearly interpolated for each annual cycle. Wind speed data were taken from averaged daily recordings at OWS M. The physical forcing data used for this period is given in Fig. 3.

\subsubsection{The ecosystem}

Phytoplankton were split into four groups: diatoms, dinoflagellates, flagellates and coccolithophores (Emiliania huxleyi). They were originally grouped in this way because they represented the most common species found in the Bering Sea (Merico et al., 2006). This appears to also be the case for the Norwegian Sea.

Zooplankton were split into two groups, these are microzooplankton and mesozooplankton. This distinction is important when considering more than one phytoplankton group because diatoms, dinoflagellates and microzooplankton are the food sources for mesozooplankton; whereas flagellates and E. huxleyi are the food sources for microzooplankton. Furthermore, although mesozooplankton, particularly copepods, have been well studied in the Nordic Seas (Dale et al., 2001; Halvorsen et al., 2003) and it is widely acknowledged that they have an important role in transferring energy to higher levels of the food web, they may be of secondary importance in terms of grazing of phytoplankton, and hence carbon flux, when compared to microzooplankton. There is a lack of microzooplankton grazing studies in the Norwegian Sea, yet reports from other areas suggest that microzooplankton impact significantly on phytoplankton populations (e.g. Burkhill et al., 1993; Calbet and Landry, 2004) and are the major loss term. The total phytoplankton is converted from nitrogen units into chlorophyll units through the $\mathrm{C}: \mathrm{N}$ ratio multiplied by the $\mathrm{Chl}: \mathrm{C}$ ratio which is calculated by adaptation to light, temperature and nutrient growth rate (Cloern et al., 1995)

The Bering Sea model included a switching parameter for grazing rate on E. huxleyi and diatoms determined by the silicate concentration. When silicate was low diatoms are assumed to be unable to produce highly silicified tests and become more vulnerable to grazers, therefore microzooplankton switch feeding from E. huxleyi to diatoms when silicate is less than $3 \mu \mathrm{mol} \mathrm{L}^{-1}$. There is little evidence from data to back up this intuitive assumption of switching in the Norwegian Sea; however, mesocosm experiments have shown that diatom dominance ceases when silicate concentration fall below 2-3 $\mu \mathrm{mol} \mathrm{L}^{-1}$ (Egge and Aksnes, 1992). There is a relatively low silicate concentration year-round within the Norwegian Sea so it may be that there is little variation in grazer selection. However this assumption was left in the model and tests are carried out of the sensitivity of the E. huxleyi and diatom populations to this grazing assumption.
Silicate and nitrate are the two main nutrients modelled here. Phosphate was not included because preliminary data analysis of OWS M data suggested that phosphate levels were not limiting.

The primary objectives of this study are to investigate the nutrient and carbon cycling within the Norwegian Sea, rather than to accurately model the phytoplankton and zooplankton processes. However, some biological detail is necessary in order to represent biological impacts on nutrient and carbon cycles, and thus the ecosystem is constrained to approximately fit the data, while at the same time acknowledging considerable uncertainty over how to correctly represent competition between different phytoplankton functional groups (Anderson, 2005).

\subsubsection{The carbonate system}

The carbonate system is forced by deep total alkalinity $\left(\mathrm{A}_{\mathrm{T} 0}\right)$, deep total dissolved inorganic carbon $\left(\mathrm{C}_{\mathrm{T} 0}\right)$ and atmospheric $p \mathrm{CO}_{2}\left(p \mathrm{CO}_{2}^{(\mathrm{atm})}\right) \cdot p \mathrm{CO}_{2}^{(\mathrm{atm})}$ was calculated as a interpolated trend taken from the annual cycle of atmospheric $\mathrm{CO}_{2}$ and then adjusted to a mean annual value of $377 \mathrm{ppm}$ (averaged from OWS M observations for the time period 2002-2006; Tans and Conway, CDIAC), because omitting this seasonal fluctuation leads to an overestimation of the flux of $\mathrm{CO}_{2}$ into the ocean during the summer period (Bellerby et al., 2005).

$\mathrm{C}_{\mathrm{T}}$ is removed from the upper layer of the water column by the consumption of inorganic carbon by phytoplankton but is added by respiration of organic material. $\mathrm{C}_{\mathrm{T}}$ is also influenced by air-sea $\mathrm{CO}_{2}$ exchange with the atmosphere and by $\mathrm{CaCO}_{3}$ formation and dissolution. Seawater $p \mathrm{CO}_{2}$ was calculated from model variables of $\mathrm{A}_{\mathrm{T}}, \mathrm{SST}$, salinity and $\mathrm{C}_{\mathrm{T}}$ along with apparent dissociation constants of carbonic acid, boric acid, the solubility of $\mathrm{CO}_{2}$ and the hydrogen ion activity by using the iterative method presented by Peng et al. (1987). Changes in surface $A_{T}$ were simply computed as the balance between calcification, dissolution, diffusive mixing and changes due to nitrate. $\mathrm{A}_{\mathrm{T}}$ in the model has not been corrected for salinity. Salinity does influence the dissociation constants, and we include a sensitivity test to assess whether there is a large impact of salinity on the carbonate ion concentration as a result of using constant or varying salinity on the dissociation constants.

\section{Data analysis}

The data were collected every month from January 2002 to December 2006 from the Norwegian Sea at Ocean Weather Station M, located at $66^{\circ} \mathrm{N}, 02^{\circ} \mathrm{E}$ on the continental slope (Skjelvan, personal communication; Skjelvan et al., 2008; Rey, personal communication, 2007). Data used here (from measurements made at $\leq 20 \mathrm{~m}$ depth) includes nitrate concentration, silicate concentration, chlorophyll, temperature, salinity, $\mathrm{C}_{\mathrm{T}}$ and $\mathrm{A}_{\mathrm{T}}$ (normalised to salinity using 


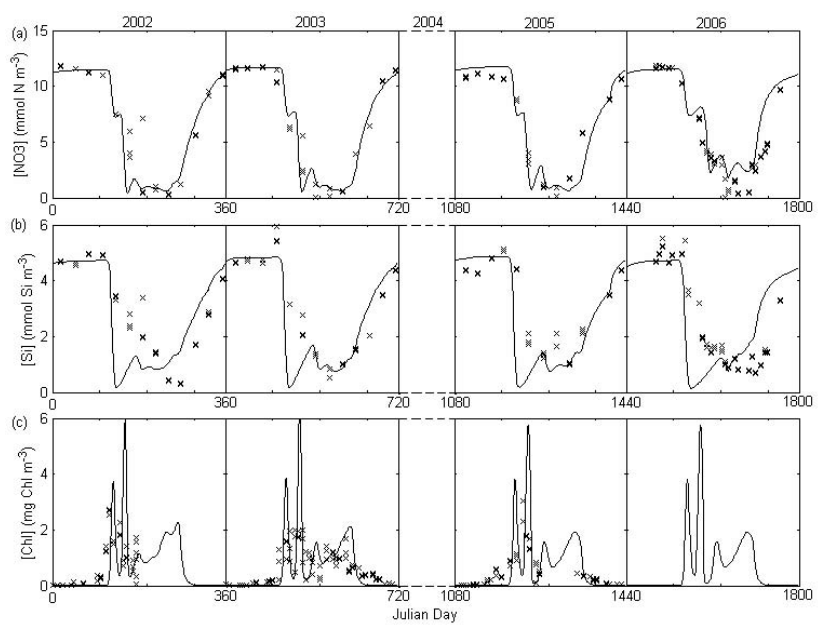

Fig. 4. The standard run output showing modelled data (black lines) and OWS M data ( $\leq 20 \mathrm{~m})$ (crosses) for (a) nitrate in years 2002, 2003, 2005 and 2006, (b) silicate in years 2002, 2003, 2005 and 2006, (c) chlorophyll in years 2002, 2003, 2005 and 2006 (no chlorophyll data available in year 2006). Year 2004 not included here because of lack of data.

Eq. (2) from Friis et al., 2003 with the intercept $\left(\mathrm{A}_{\mathrm{T}}\right.$ $(\mathrm{SSS}>34.5)=49.35 * \mathrm{SSS}+582(\mathrm{r} 2=0.86, \mathrm{n}=2478)$, taken from Nondal et al., submitted)).

\section{Results}

\subsection{The standard run}

\subsubsection{The nutrients}

The OWS M data show that nitrate (Fig. 4a) is removed from the surface layer after $\sim$ JD 120 (April) at a rate of about $0.183 \mathrm{mmol} \mathrm{m}^{-3} \mathrm{~d}^{-1}$ and becomes limiting (i.e. $<1 \mathrm{mmol} \mathrm{m}^{-3}$ ) by $\sim$ JD 180 (July). Nitrate remains at relatively low concentrations until $\sim$ JD 240 when there is a more gradual increase $\left(\sim 0.12 \mathrm{mmol} \mathrm{m}^{-3} \mathrm{~d}^{-1}\right)$ as a result of crossthermocline mixing and entrainment from the deep ocean as stratification breaks down. Maximum values are not reached until January. There is some interannual variability in the surface nitrate data during the summer seasons; however it does appear to reach $<1 \mathrm{mmol} \mathrm{m}^{-3}$.

Silicate (Fig. 4b) decreases slowly during the spring and summer (at a rate of $\sim 0.05 \mathrm{mmol} \mathrm{m}^{-3} \mathrm{~d}^{-1}$ ), reaching a minimum by August but almost immediately increasing again, while in another year (2005) it can be seen to decrease more rapidly $\left(\sim 0.13 \mathrm{mmol} \mathrm{m}^{-3} \mathrm{~d}^{-1}\right)$ but then fluctuate between $1 \mathrm{mmol} \mathrm{m}^{-3}$ and $2 \mathrm{mmol} \mathrm{m}^{-3}$ over the summer before increasing back to the winter maximum.

The standard run of the model (Fig. 4) demonstrates a similar pattern of nitrate consumption. Concentration decreases relatively rapidly during spring, remaining at relatively low

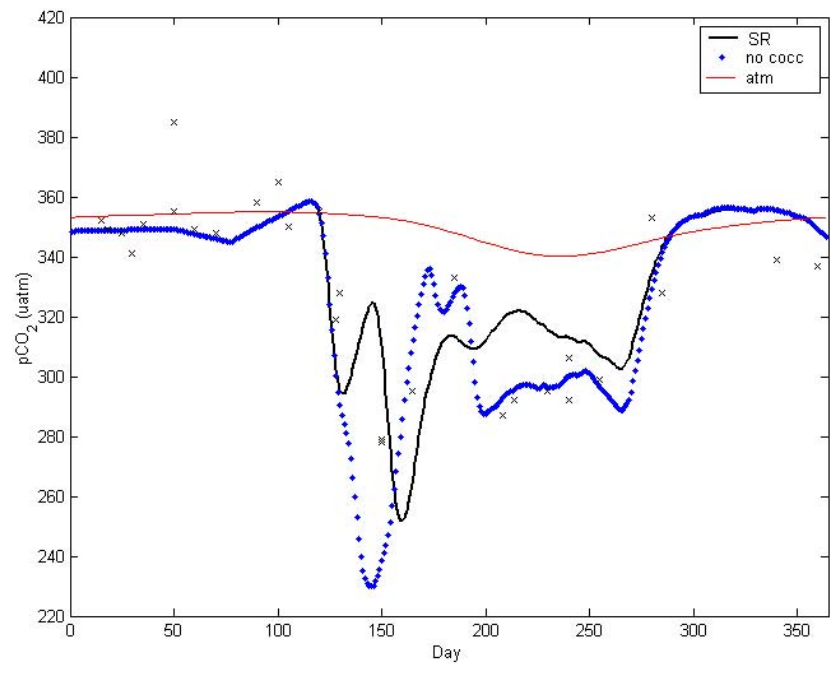

Fig. 5. Modelled output of carbon dioxide partial pressure in air (thin red line) and seawater with the standard run (thick black line) and with no coccolithophores (thick dot blue line) (averaged over the four modelled years). Data points (crosses) represent observed carbon dioxide partial pressure in seawater taken from Gislefoss et al. (1998). The data points are from 1993 and 1994 and hence they are at lower $p \mathrm{CO}_{2}$ than the current model is set to. Modelled output has therefore been shifted down by $20 \mathrm{ppm}$ to fit data points demonstrating the pattern and magnitude of the seasonal cycle.

concentrations over the summer and then slowly increasing back to the winter maximum value. The standard run is not able to reproduce the slow decline in silicate seen in 2002 and 2003, but is able to reproduce the more typical rapid decline in silicate as a result of diatom consumption seen in many other temperature locations (e.g. Merico et al., 2004; Takahashi et al., 1993) and seen in the Norwegian Sea data in 2005.

\subsubsection{The carbonate system}

Figure 5 shows the standard run of the atmospheric and surface water $p \mathrm{CO}_{2}$ alongside data points from Gislefoss et al. (1998). The data points are from 1993 and 1994 and hence are at lower $p \mathrm{CO}_{2}$ than this model is set to. Modelled output has been shifted down by $20 \mathrm{ppm}$ to demonstrate the similarities between the pattern and magnitude of the seasonal cycle. Exact values are of less concern and hence we feel justified in making this comparison. Figure 5 illustrates the atmospheric and surface water $p \mathrm{CO}_{2}$ when there are no coccolithophores present in the model (blue dots).

Without any biology in the model, a slight increase in $\left[\mathrm{CO}_{3}^{2-}\right]$ over the summer period occurs as a result of loss of $\mathrm{CO}_{2}$ to the atmosphere through changes in the $p \mathrm{CO}_{2}$, and the seasonal amplitude of calcite saturation state is small $(0.4$ units). This does not, however, fit the observed changes in $\left[\mathrm{CO}_{3}^{2-}\right]$ seen in the data. $\left[\mathrm{CO}_{3}^{2-}\right]$ and $\left[\mathrm{C}_{\mathrm{T}}\right]$ in the standard run (with biology, SR in Figure 6) follow similar patterns 

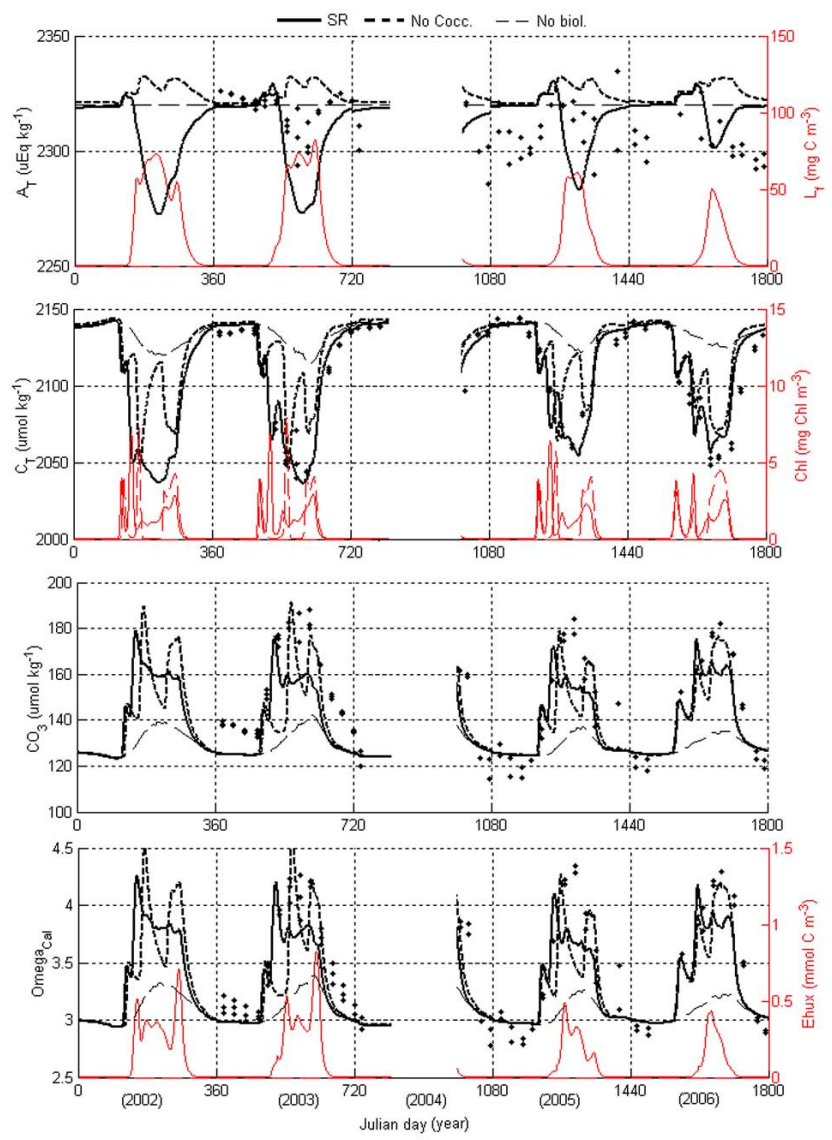

Fig. 6. Model output for carbonate system showing standard run including all biological groups (thick line), run with all biology turned off (thick dashed line) and run with all biological groups except coccolithophores (thin dashed line). Model results are compared to data (crosses). (a) $\mathrm{A}_{\mathrm{T}}$ (black) and free coccoliths (red), (b) $\mathrm{C}_{\mathrm{T}}$ (black) and chlorophyll concentration (red), (c) carbonate ion concentration and (d) calcite saturation state (black) and coccolithophore concentration (red).

to the data: $\left[\mathrm{CO}_{3}^{2-}\right]$ increases over the summer period (from $\sim 120$ to $\sim 170 \mu \mathrm{mol} \mathrm{kg}^{-1}$ ) as a result of biological consumption of $\mathrm{C}_{\mathrm{T}}$. This causes an increase in $\Omega_{\text {cal }}$ from about 3 to 4 following the spring bloom. $\mathrm{A}_{\mathrm{T}}$ and carbonate ion data have large interannual variability, which is not reproduced in the model. Modelled $\mathrm{A}_{\mathrm{T}}$ and $\left[\mathrm{CO}_{3}^{2-}\right]$ are both low in years 2004 and 2005 compared to the data, particularly when coccolithophores are included (SR in Fig. 6). This could imply that coccolithophores blooms did not occur during these years. During the coccolithophore growth period over the late summer in 2002 and 2003, there is a decrease in model $\mathrm{A}_{\mathrm{T}}$ by about $38 \mu \mathrm{Eq} \mathrm{kg}{ }^{-1}$, as a result of $\mathrm{CaCO}_{3}$ formation by production of coccoliths. This matches the summer decline which is seen in the $A_{T}$ data in 2003 but not in either 2005 or 2006.
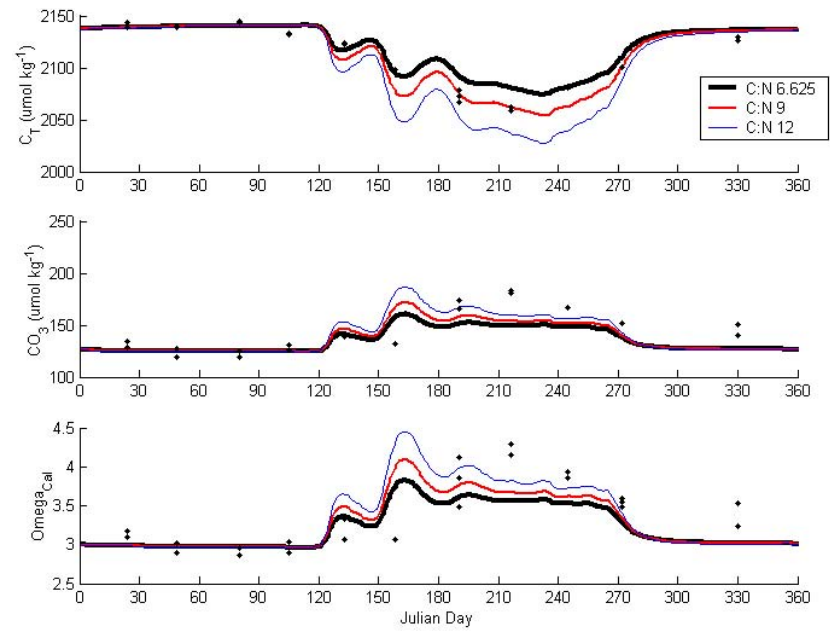

Fig. 7. Sensitivity analysis of the $C: N$ ratio. Showing $C_{T}(a), C_{3}^{-2}$ concentration (b) and calcite saturation state (c) for the standard run where the $\mathrm{C}: \mathrm{N}=6.6$ high $\mathrm{C}: \mathrm{N}=12$ and mid $\mathrm{C}: \mathrm{N}$ ratio=9. The dots represent the combined OWS M data $(\leq 20 \mathrm{~m})$ from the period 2002-2006.

\subsection{Sensitivity analysis}

There are some discrepancies between the standard run model output and the data - most notably the silicate removal in spring. Sensitivity analyses were carried out to establish if the model could produce a better fit under different scenarios of forcing, grazing and growth rates. The sensitivity analyses also demonstrate why the standard parameters were chosen. A Monte Carlo parameter sensitivity test was conducted for 200 model runs to investigate the suitability of the chosen parameters to reproduce the nitrate and silicate drawdown rates and the maximum chlorophyll concentration. In addition we created a Taylor diagram (Taylor, 2001) to demonstrate the ability of different model versions (full model and model without coccolithophores) to fit the data. The carbonate ion concentration was not sensitive to the forcing of either constant salinity (mean year salinity) or the data-derived salinity on the dissociation constants (results are not shown).

\subsubsection{C:N ratio}

It has recently been argued that the original Redfield ratio of $\mathrm{C}: \mathrm{N}$ is not correct for all circumstances (Takahashi et al., 1985; Sambrotto et al., 1993; Anderson and Sarmeinto, 1994; Brostrom, 1998; Kahler and Koeve, 2001; Kortzinger et al., 2001; Falck and Anderson, 2005). Model sensitivity for $\mathrm{C}: \mathrm{N}$ ratio demonstrated that a ratio of 1:6.6 (C:N) underestimated the $\mathrm{C}_{\mathrm{T}}$ consumption over the summer period (Fig. 7). When the ratio was increased to 1:9 the fit was much closer; and a high ratio (1:12) overestimated the carbon system values. A ratio of 1:9 was therefore considered the most appropriate and was used in the standard run and all further analyses. 

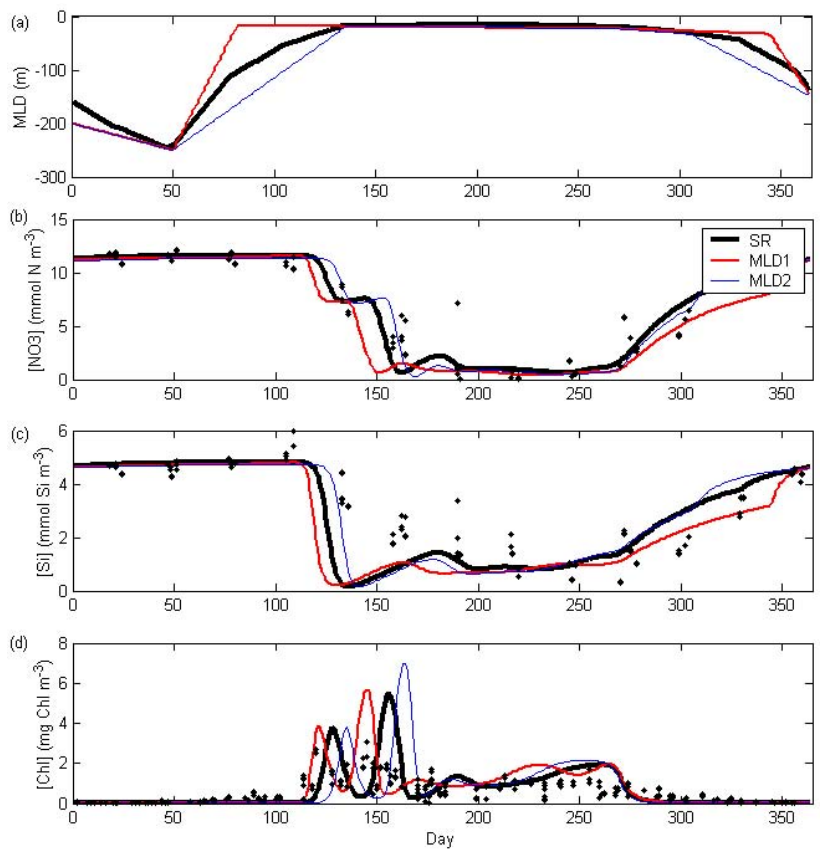

Fig. 8. Sensitivity of (a) MLD, (b) nitrate concentration, (c) silicate concentration, and (d) chlorophyll concentration in standard run (SR) compared to rapid shoaling and deepening of the mixed layer (MLD1) and slow shoaling and deepening of the mixed layer (MLD2). The dots represent the combined OWS M data $(\leq 20 \mathrm{~m})$ from the period 2002-2006.

\subsubsection{Mixed layer depth}

The MLD varies interannually; the timing and rate of shoaling of the mixed layer combined with levels of irradiance determines when the spring bloom occurs and its magnitude. Figure 8 shows three simulations of MLD: a rapidly shoaling and deepening mixed layer (MLD1) and a slowly shoaling and deepening mixed layer (MLD2) and an intermediate mixed layer (SR). MLD1 does not greatly alter the system during the spring bloom because at this time phytoplankton are limited by light; however the more rapid deepening in autumn stimulates an autumn phytoplankton bloom which maintains the nutrients and $\mathrm{C}_{\mathrm{T}}$ at lower concentrations for a longer period into winter. MLD2 slows the shoaling of the mixed layer and hence the phytoplankton remain below the critical depth for a longer period of time. Alternative MLD variations do not improve the agreement with data and so are not used.

\subsubsection{Growth rate of diatoms and flagellates}

The OWS M data suggests that consumption of nitrate and silicate does not occur at equal rates as would be expected for a spring bloom dominated by diatoms (Fasham et al., 2001). In fact silicate is depleted much more slowly. In order to assess why this happens the growth rates for diatoms
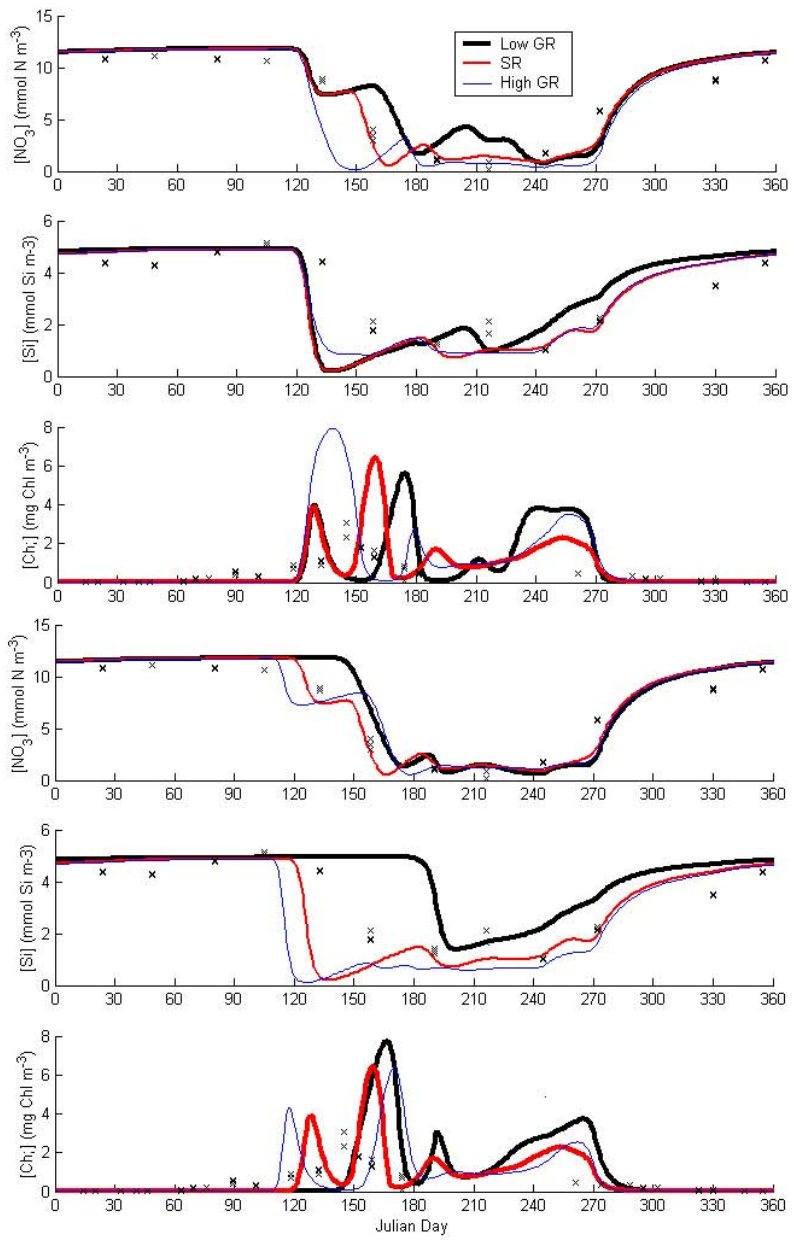

Fig. 9. Sensitivity of nitrate concentration (a) and (d), silicate concentration (b) and (e), and chlorophyll concentration (c) and (f) to changes in diatom $(a, b, c)$ and flagellate $(d, e, f)$ growth rates (standard run (SR), 50\% higher growth rate (high GR) and 50\% lower growth rate (low GR)). The black represent the combined OWS M data $(\leq 20 \mathrm{~m})$ from the period 2002-2006.

(Fig. 9a-c) and flagellates (Fig. 9d-f) were both increased and decreased by $50 \%$ of the standard parameter. When the growth rates are lower the diatoms are inhibited from blooming, the flagellates then bloom later, along with a larger coccolithophore bloom ( JD 160 compared to $\sim$ JD 140) causing a greater overall increase in chlorophyll than during the SR ( $\sim 9.5 \mathrm{mg} \mathrm{Chl} \mathrm{m}^{-3}$ compared to $\sim 5.5 \mathrm{mg} \mathrm{Chl} \mathrm{m}^{-3}$ ). Silicate is not reduced until later in the summer when diatoms are finally able to bloom. Nitrate does not reach low concentrations over the summer as a result of the limited population growth. High growth rate allows the populations to bloom earlier in the spring ( JD 110, $\sim 7 \mathrm{mg} \mathrm{Chl} \mathrm{m}^{-3}$ ), rapidly depleting both nitrate and silicate. The high growth rate causes the phytoplankton and zooplankton to fall into tightly coupled predator-prey cycles. 

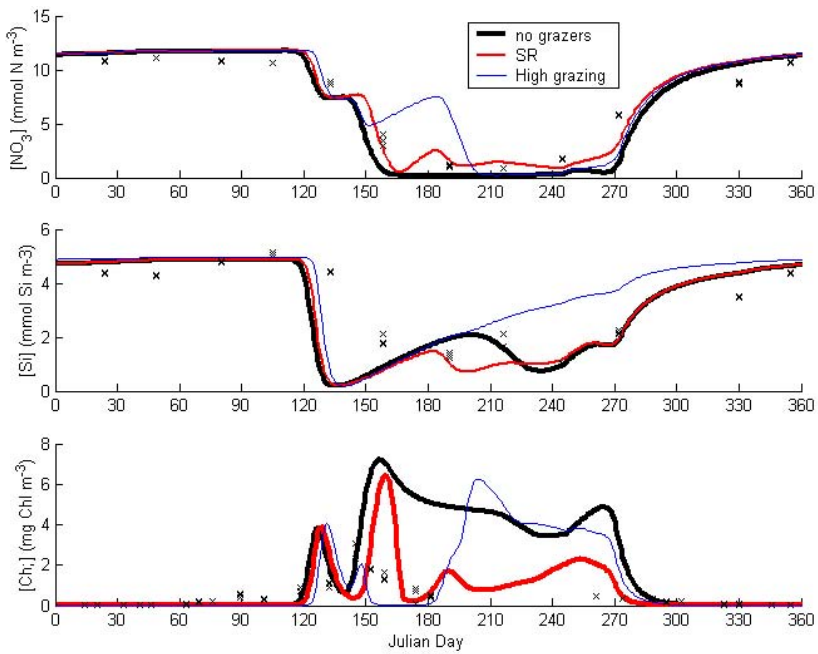

Fig. 10. Sensitivity of (a) nitrate concentration, (b) silicate concentration, (c) total chlorophyll concentration, to changes in grazing rates: standard run (SR), no grazers are present (no grazer) and when grazing rates are increased by $50 \%$ (high grazing). The dots represent the combined OWS M data $(\leq 20 \mathrm{~m})$ from the period 2002-2006.

\subsubsection{Grazing}

Microzooplankton and mesozooplankton occur at different times over the annual cycle. Microzooplankton are set to graze more efficiently on coccolithophores when the silicate concentration is $>3 \mathrm{mmol} \mathrm{m}^{-3}$ but then switch to grazing on diatoms when the silicate concentration falls below $3 \mathrm{mmol} \mathrm{m}^{-3}$. Silicate is low in the Norwegian Sea $\left(\sim 5 \mathrm{mmol} \mathrm{m}^{-3}\right.$ compared to $\sim 30 \mathrm{mmol} \mathrm{m}^{-3}$ prior to the spring blooms in the Bering Sea) therefore the switching becomes almost irrelevant. Mesozooplankton concentration is low and is food-limited mainly by the dinoflagellate population. With no grazers (i.e. all grazing rates set to zero in the model; Fig. 10) the nutrients follow a similar pattern over the annual cycle, except that they are maintained at limiting concentrations over the summer by the uncontrolled phytoplankton. There are, however, differences within the phytoplankton: the diatom bloom is similar in spring but have a second growth period in late summer (between JD 220 and JD 270); flagellates grow uncontrolled and become nitrate limited after JD 150 although their population declines only slowly throughout the summer maintaining nitrate at low levels. Dinoflagellates and coccolithophores are out-competed by the flagellates with no apparent growth over the year. When grazing rates are increased (by $50 \%$ of standard run) the initial bloom is delayed marginally but the diatoms are still able to grow and consume all the silicate; nitrate is not fully consumed and remains relatively high over the summer period.
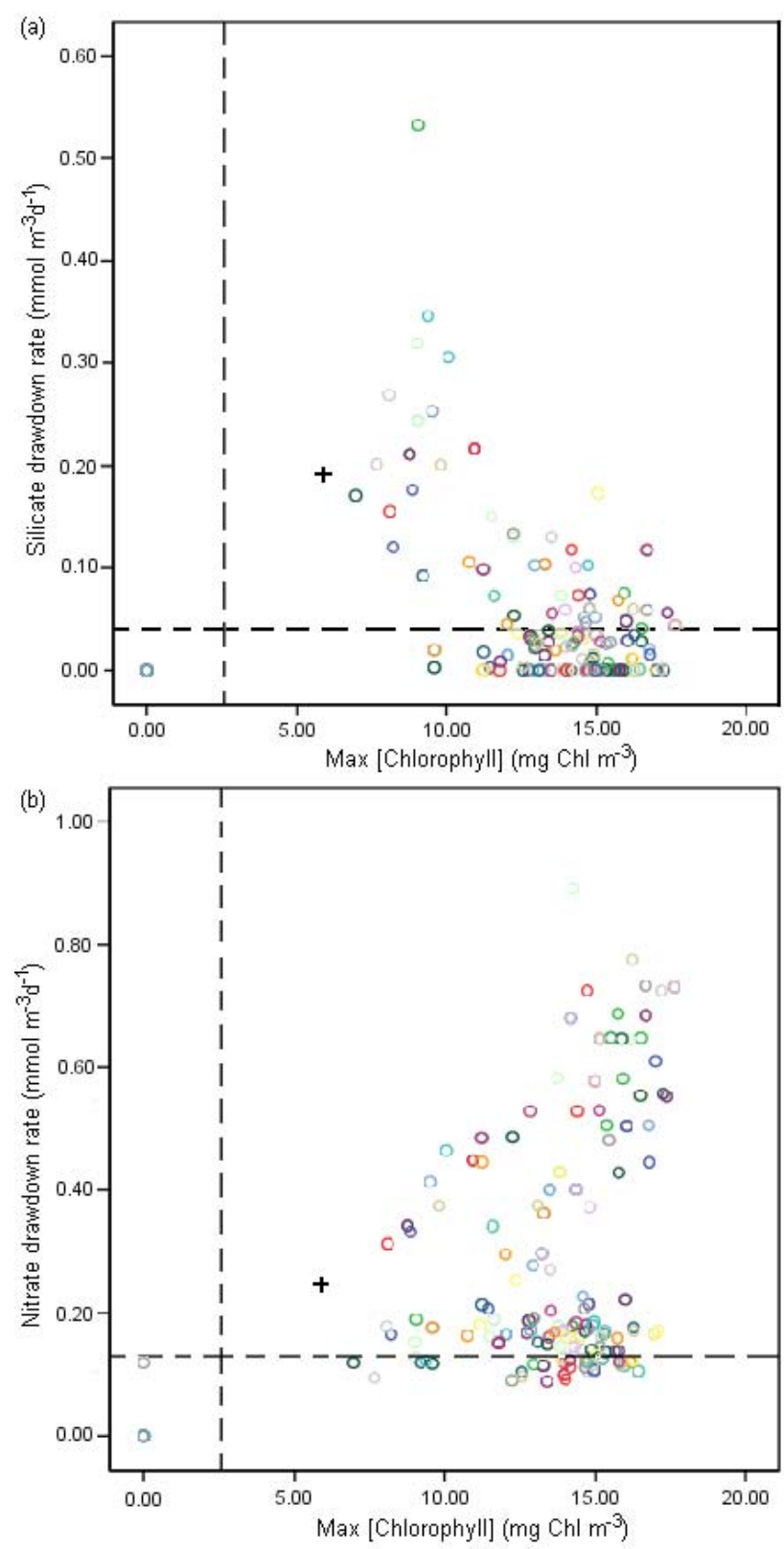

Fig. 11. Monte Carlo parameter test of 200 model runs showing (a) silicate drawdown rate vs maximum chlorophyll concentration and (b) nitrate drawdown rate vs maximum chlorophyll concentration. The crosses mark the standard parameter values and the coloured circles each represent a different run. The dashed lines represent the drawdown rates and chlorophyll maximum values from the data.

\subsubsection{Monte Carlo parameter optimization}

Using random values within a specified range for each parameter (the range was chosen for each parameter based on values from the literature), we produced outputs of 200 model runs and examined whether it was possible for the model to reproduce the silicate consumption rate, nitrate 


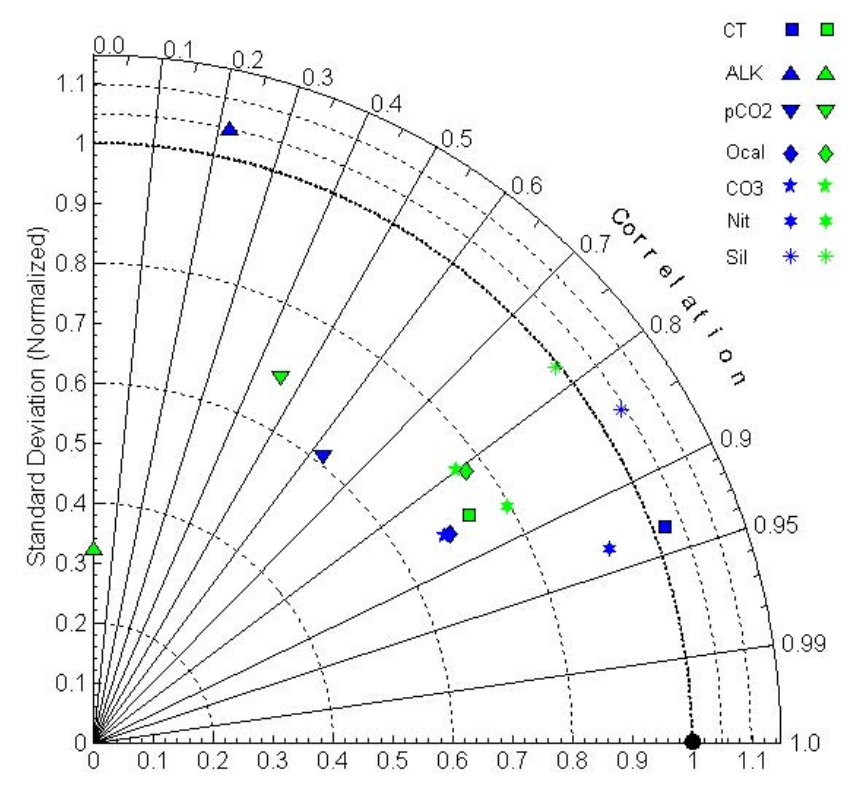

Fig. 12. Taylor diagram showing normalised standard deviations and correlation coefficients for dissolved inorganic carbon (DIC, squares), alkalinity (Alk, up-pointing triangles), $p \mathrm{CO}_{2}\left(p \mathrm{CO}_{2}\right.$, down-pointing triangles), $\Omega_{\text {Calcite }}$ (Ocal, diamonds), $\mathrm{CO}_{3}^{2-}\left(\mathrm{CO}_{3}\right.$, 5-point star), nitrate (nit, 6-point star) and silicate (Sil, cross) for two different forms of the model compared to data. The models are: the full model (Full, blue) and the model with no coccolithophores (No Cocc., green). Data and model comparisons are for available data during 2002, 2003, 2004, 2005 and 2006. The black circle shows the result that would be obtained for a perfect fit between model and data (identical standard deviations and correlation coefficient of 1.0).

consumption rate and maximum chlorophyll concentration found in the data (averaged over four years, 2002, 2003, 2005 and 2006). We found that many model runs produced realistic silicate and nitrate consumption rates whereas none produced realistic maximum chlorophyll concentrations. The difficulty that we found for the standard run, in terms of reproducing the relatively slow decline in silicate, is therefore shown by the Monte-Carlo analysis to be of lesser importance, because other combinations of parameters values allow it to be correctly simulated. However, there were no scenarios using suitable parameter values which allowed both the correct consumption of nitrate and silicate at the same time as only producing a small bloom in phytoplankton. Figure 11 demonstrates that all the parameter sets gave maximum chlorophyll concentrations that were much greater than the average data value and the standard run value.

We suggest that there are two possible explanations for this model-data misfit. Firstly, it could be that the periodic sampling just happened to miss the peaks of the ephemeral phytoplankton blooms in all of the four years. Secondly, it could be that the model is insufficient in the sense of not including some key process or state variable that is essential in
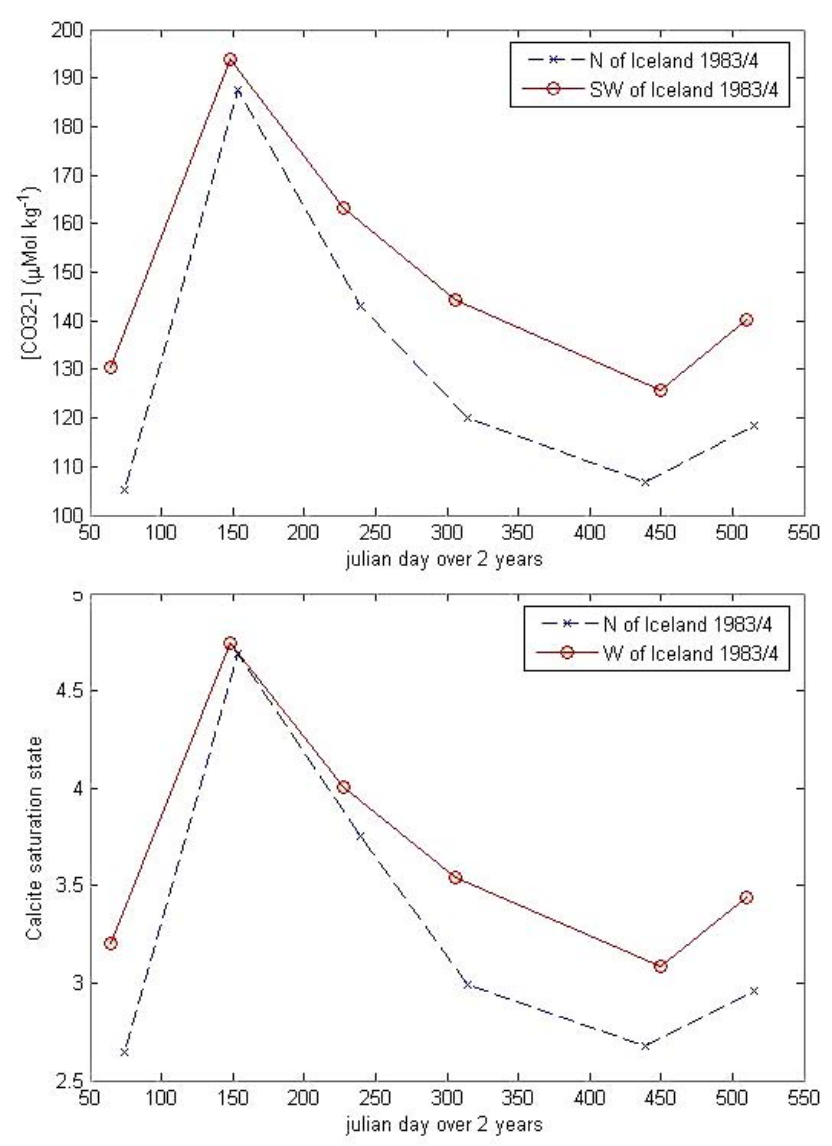

Fig. 13. Calculated seasonal cycles of (a) carbonate ion concentration and (b) calcite saturation state for north and south of Iceland (data taken from Table 2 of Takahashi et al., 1985).

order to correctly simulate phytoplankton ecosystem dynamics in the Norwegian Sea. Again there could be some other factors, which are not incorporated into the model, that control the blooming of phytoplankton at OWS M and prevent them from achieving a large bloom

\subsubsection{Taylor diagram}

In order to assess the best model fit to data we have applied the use of a Taylor diagram to illustrate the correlation and the normalised standard deviation. The distance on the plot between the solid black circle (perfect reproduction of the data) and any other symbol is also indicative of the rootmean-square difference between the data and model points (Taylor, 2001). Two model variants were used: the full model and the model without coccolithophores. Figure 12 illustrates that the full model (blue symbols) over the whole 5 year data set, has relatively good correlation to data with respect to $\mathrm{C}_{\mathrm{T}}$ and nitrate. Silicate is less well correlated but the standard deviations are very similar. $\Omega_{\text {cal }}$ and $\mathrm{CO}_{3}^{2-}$ are also reasonably correlated but the model results do not possess as large a standard deviation as the data. Alkalinity is less well 
correlated but shows good resemblance to the variation of the data. When the no coccolithophore model is used (Fig. 12, green symbols), all variables become less correlated with the data than when using the full model. All the variables except for nitrate, $\mathrm{C}_{\mathrm{T}}$ and alkalinity have a slightly better representation of the variation in the data; alkalinity, nitrate and $\mathrm{C}_{\mathrm{T}}$ all have lower standard deviations.

\section{Discussion}

\subsection{The ecosystem and nutrient dynamics}

In this section we compare the seasonal patterns of phytoplankton and nutrients at OWS M to those at several other locations, and conclude that some factor (possibly iron limitation) restricts phytoplankton growth at OWS M in some years.

\subsubsection{Nitrate}

Previous data suggest that in some years Norwegian Sea nitrate concentrations never reach limiting levels, while in other years nitrate is fully depleted but not until later in summer (Kohly, 1998; Dale et al., 1999; Haupt et al., 1999). Neither the model nor the data shown here agree with these previous observations. Minimum nitrate for 2002, 2003, 2005 and 2006, respectively, is $0.35,0.43,0.52$ and $1.79 \mathrm{mmol} \mathrm{N} \mathrm{m}^{-3}$ in the model and $0.26,0.02,0.18$ and $0.03 \mathrm{mmol} \mathrm{N} \mathrm{m}^{-3}$ in the data (Fig. 4). This behaviour at OWS M (slow and/or incomplete nitrate depletion in some years) is somewhat at odds with the more commonly observed pattern in temperate and sub-polar waters: that nitrate and silicate are rapidly exhausted as a consequence of intense spring phytoplankton blooms, and then remain scarce throughout summer. Such a situation is seen in, for example: (1) the eastern Bering Sea (Merico et al, 2004), (2) the Irish Sea (Tyrrell et al, 2005), (3) the Baltic Sea (Larsson et al, 2001), and (4) the North Atlantic at $\sim\left(47^{\circ} \mathrm{N}, 20^{\circ} \mathrm{W}\right)$ (Fasham et al., 2001; Takahashi et al., 1993), and (5) north of Iceland at about $\sim\left(68^{\circ} \mathrm{N}, 19^{\circ} \mathrm{W}\right)$ (Takahashi et al, 1993). On the other hand, residual summer nitrate has also been observed in the Irminger Basin between Iceland and Greenland (Henson et al., 2003; Takahashi et al., 1993), east of Iceland at $\sim\left(64^{\circ} \mathrm{N}, 10^{\circ} \mathrm{W}\right)$ (Allen et al., 2005), and at $\sim\left(60^{\circ} \mathrm{N}, 20^{\circ} \mathrm{W}\right)$ in the North Atlantic (Taylor et al., 1993).

\subsubsection{Silicate}

The OWS M silicate data do not agree with the simulations. In the model, diatoms bloom but soon become limited by rapidly depleting silicate, which is already at a fairly low concentration prior to the spring blooms. This results in them only having a relatively short bloom. The pattern in the data is very different (Fig. 8). Silicate is not rapidly consumed in any of the four years (Fig. 4), implying that either the diatoms are not rapidly blooming (even though silicate should only become limiting to blooms at $<2 \mathrm{mmol} \mathrm{m}^{-3}$, Egge and Aksnes, 1992) or else that there is an influx of silicate which is able to counterbalance any rapid consumption.

\subsubsection{Chlorophyll}

The peak springtime chlorophyll concentrations $(\leq 3 \mathrm{mg}$ chl$a \mathrm{~m}^{-3}$, Figure 4) observed at OWS M between 2002 and 2006 are quite low compared to other locations in shelf seas, e.g. $16 \mathrm{mg}$ chl- $a \mathrm{~m}^{-3}$ in the eastern Bering Sea (Merico et al., 2004) and $\sim 11 \mathrm{mg}$ chl- $a \mathrm{~m}^{-3}$ in the Irish Sea (Tyrrell et al., 2005). Similar small maximum values have however been observed in other (open-ocean) settings such as the Labrador Sea (2-3 mg chl- $a \mathrm{~m}^{-3}$, Boss et al., 2008) and the North Atlantic at $\sim\left(47^{\circ} \mathrm{N}, 20^{\circ} \mathrm{W}\right)\left(\sim 3 \mathrm{mg}\right.$ chl- $a \mathrm{~m}^{-3}$ : Fasham et al., 2001). However, the bloom chlorophyll levels observed in the Norwegian Sea are significantly greater than typical annual maxima in HNLC areas which are usually $\leq 1 \mathrm{mg}$ chl$a \mathrm{~m}^{-3}$ (for instance the Subarctic Northeast and Northwest Pacific and the Southwest Bering Sea, Tyrrell et al., 2005; Boyd et al., 1998). The Monte-Carlo parameter analysis suggests that out of 200 model runs, with parameter values allocated randomly within ranges determined from the literature, it was not possible to create the small chlorophyll maximum seen in the data, yet the model appears to have a good correlation to the data in terms of $\mathrm{C}_{\mathrm{T}}$ and nitrate annual cycles.

\subsubsection{Interpretation}

The slow and/or incomplete exhaustion rates of nitrate and, especially, silicate, at OWS M are atypical compared to some other locations. Various hypotheses have been proposed to explain this phenomenon including grazer levels (Taylor et al., 1993, as an explanation for residual summer nitrate at $60^{\circ} \mathrm{N}, 20^{\circ} \mathrm{W}$ in the North Atlantic) and silicate-limited growth of diatoms (Dale et al., 1999).

Analyses of longer term datasets for this area agree that there are low chlorophyll levels during the spring bloom and there is slow silicate consumption, although there is more variability over longer time periods (Rey, personal communication, 2007). They suggest that the preferential grazing of zooplankton on diatoms may explain the relatively slow depletion of silicate. However, the selective grazing function in our model does not prevent the rapid blooming of diatoms in the spring, thus neither reproducing the observed low chlorophyll levels nor a slow silicate drawdown; studies have shown that the dominant zooplankton grazers in the Norwegian Sea, Calanus helgolandicus andCalanus finmarchicus (Gaard, 2000) both have reduced reproductive output during diatom dominated blooms and hence preferentially graze on non-diatom species (Nejstgaard et al., 2001).

The data from OWS M clearly show that it is not a full High Nutrient Low Chlorophyll (HNLC) area, as, although 
peak chlorophyll concentrations are low, they are not as low as in true HNLC areas and nutrient concentrations do fluctuate considerably across the seasonal cycle. Previous work suggests that phytoplankton growth in spring in the North Atlantic is influenced by levels of iron (Moore et al., 2006). This raises the question as to whether spring blooms at OWS $\mathrm{M}$ could also be restrained by low levels of iron in some years. OWS M lies on the continental slope and is subject to different conditions to shelf seas, but is also not an open ocean system. One possible explanation of the low chlorophyll levels and slow/incomplete nutrient depletion in some years could be that iron scarcity inhibits large phytoplankton blooms during some years but not others. The interannual variability could thus potentially be explained by the advection of coastal waters across OWS M only in some years (this often occurs around August time, as determined from sea surface salinity measurements). Coastal and shelf waters typically have higher iron content due to iron release from sediments (e.g. Aguilar-Islas et al., 2007).

\subsection{Local $\mathrm{CO}_{2}$ sink strengths}

The annual cycle of carbon dioxide partial pressure in the surface waters $\left(\mathrm{pCO}_{2(S W)}\right)$ has been explored here. At the start of the year $\mathrm{pCO}_{2(\mathrm{SW})}$ decreases as a result of the colder water temperatures and the continued vertical exchange of carbon that carries on until the summer pycnocline has formed. The spring bloom rapidly consumes $\mathrm{CO}_{2}$ from the surface water and hence decreases the partial pressure, (by up to $100 \mu \mathrm{atm}$ ) (Fig. 5). The removal of $\mathrm{pCO}_{2 \text { (SW) occurs }}$ throughout the summer until the breakdown of stratification and the end of biological production.

For the first part of the year until the end of the biological production period, the waters act as a sink for carbon dioxide, with an average model $\mathrm{CO}_{2}$ flux of $37 \mathrm{~g} \mathrm{C} \mathrm{m}^{-2} \mathrm{yr}^{-1}$ from the atmosphere to the surface water. Falck and Anderson (2005) calculated a flux of $\mathrm{CO}_{2}$ of $32 \mathrm{~g} \mathrm{C} \mathrm{m}^{-2} \mathrm{yr}^{-1}$ for OWS M data during 1991-1994 and Skjelvan et al. (2005) suggest $20 \mathrm{~g} \mathrm{C} \mathrm{m}^{-2} \mathrm{yr}^{-1}$ for the Norwegian Sea. Other estimates for the Nordic Seas area include a flux of $53 \mathrm{~g} \mathrm{C} \mathrm{m}^{-2} \mathrm{yr}^{-1}$ into the Greenland Sea (Anderson et al., 2000) and $69 \mathrm{~g} \mathrm{C} \mathrm{m}^{-2} \mathrm{yr}^{-1}$ into the Iceland Sea (Skjelvan et al., 1999). The variability in fluxes between locations in the Nordic Seas may result from the varying amounts of primary production, the varying hydrographic conditions and/or the different water masses occurring at each location.

5.3 Comparison to other carbonate system measurements in waters with abundant coccolithophores

\subsubsection{Alkalinity}

Robertson et al. (1994), in the North Atlantic, south of Iceland, gives $\mathrm{A}_{\mathrm{T}}$ values within areas that do not have coccolithophores present of about $2330 \mu \mathrm{Eq} \mathrm{kg}^{-1}$ (comparable to the modelled winter values in the Norwegian Sea: $2320 \mu$ $\mathrm{Eq} \mathrm{kg}^{-1}$ ). Areas where coccolithophore blooms had occurred, gave lower $\mathrm{A}_{\mathrm{T}}$ values (lowest $\mathrm{A}_{\mathrm{T}}<2290 \mu \mathrm{Eq} \mathrm{kg}^{-1}$ at approximately $63^{\circ} \mathrm{N}, 22^{\circ} \mathrm{W}$ ). This implies that areas harbouring intense coccolithophore blooms can experience reductions in $A_{T}$ of about $50-60 \mu \mathrm{Eq} \mathrm{kg}^{-1}$. These decreases were not due to either nitrate or salinity effects on alkalinity because differences in the two parameters were small in the study area (Holligan et al., 1993a). We can assume that about $20 \mu \mathrm{Eq} \mathrm{kg}^{-1}$ of the alkalinity change is due to salinity reductions (Skjelvan et al., 2008); however there remains a contribution by calcification of about $30 \mu \mathrm{Eq} \mathrm{kg}^{-1}$. Satellite data confirm this view: SeaWiFS derived calcite concentrations for the OWS M location range from about $0.5 \mathrm{mmol} \mathrm{CaCO}_{3}-$ $\mathrm{C} \mathrm{m}^{-3}$ in winter to a maximum of $4 \mathrm{mmol} \mathrm{CaCO}_{3}-\mathrm{C} \mathrm{m}^{-3}$ in summer in some years (SeaWiFS Project, 2006). These values are in agreement with values of modelled calcite, produced as free coccoliths (range from $0 \mathrm{mmol} \mathrm{C} \mathrm{m}^{-3}$ to 3.5 $\mathrm{mmol} \mathrm{C} \mathrm{m}^{-3}$ ). Interestingly, SeaWiFS images show that coccolithophore blooms commonly occur along the Norwegian coast but sometimes also extend out as far as the shelf break where OWS M is situated (SeaWiFS Project, 2006).

\subsubsection{Dissolved inorganic carbon}

$\mathrm{C}_{\mathrm{T}}$ concentration in the Norwegian Sea in winter was about $2140 \mu \mathrm{mol} \mathrm{kg}^{-1}$, while in June-July it was about $2080 \mu \mathrm{mol} \mathrm{kg}^{-1}$, which is a similar value to noncoccolithophore bloom areas in July 1991 in the North Atlantic (Robertson et al., 1994). The lowest $C_{T}$ concentration reached in the Norwegian Sea was about $2050 \mu \mathrm{mol} \mathrm{kg}^{-1}$, again similar to values measured south of Iceland. Takahashi et al. (1993) show that in the northeastern North Atlantic $C_{T}$ declined by about $60 \mu \mathrm{mol} \mathrm{kg}^{-1}$ during the phytoplankton bloom period in late March through to late May (during the North Atlantic Bloom Experiment study in 1989).

\subsubsection{Carbonate ion and calcite saturation state}

Merico et al. (2006) modelled the seasonal cycle of carbonate chemistry in the eastern Bering Sea (specific location: $56.8^{\circ} \mathrm{N}, 164^{\circ} \mathrm{W}$ ). The model calculated considerable seasonal variation in both carbonate ion (winter $\sim 100 \mu \mathrm{mol} \mathrm{kg}^{-1}$, summer $\sim 150 \mu \mathrm{mol} \mathrm{kg}^{-1}$ ) and calcite saturation state (winter $\sim 2.5$, summer $\sim 3.5$ ). Both variables were low in winter, rose sharply at the time of the spring blooms, and then stayed high during the summer until declining in autumn due to mixing. There was, however, a lack of data with which to test these model results in the eastern Bering Sea. In contrast, data are available for model comparison in this study. Our results from the Norwegian Sea shelf break (Ocean Weather Station M, $66^{\circ} \mathrm{N}, 2^{\circ} \mathrm{E}$ ) agree in outline with the model predictions for the eastern Bering Sea (compare Fig. 5 in Merico et al., 2006 and Fig. 6 of this paper). The Norwegian Sea data also show 
a seasonal oscillation in carbonate ion concentration (winter $\sim 130 \mu \mathrm{mol} \mathrm{kg}^{-1}$, summer $\sim 180 \mu \mathrm{mol} \mathrm{kg}^{-1}$ ) and in calcite saturation state (winter $\sim 3$, summer $\sim 4$ ). Although the seasonal changes are very similar, absolute values of both variables are slightly higher in this study than in Merico et al., (2006). The $\sim 50 \mu \mathrm{mol} \mathrm{kg}^{-1}$ amplitude of the carbonate ion seasonal cycle found in both this study and the study by Merico et al. (2006) is somewhat higher than was suggested elsewhere: "surface $\left[\mathrm{CO}_{3}^{2-}\right]$ varies by about $\pm 15 \mu \mathrm{mol} \mathrm{kg}-1$ when averaged over large regions." (Orr et al., 2005). The seasonal pattern in $\Omega_{\text {cal }}$ is predominantly determined by the spring diatom blooms, because the intense $\mathrm{C}_{\mathrm{T}}$ removal has the effect of driving up carbonate ion concentrations (Merico et al., 2006).

Annual averages of $\left[\mathrm{CO}_{3}^{2-}\right]$ and $\Omega_{\mathrm{cal}}$, but not seasonal patterns, can also be compared to the GLODAP dataset (Key et al., 2004). This is a global dataset of carbonate chemistry $\left(\mathrm{C}_{\mathrm{T}}\right.$ and Alkalinity) measurements from open ocean cruises. Average annual values are calculated, with possible biases due to sampling of many locations at only one time of year (e.g. scarcity of winter measurements at high latitudes). The dataset does not extrapolate to the Norwegian Sea, but for the open North Atlantic at $60^{\circ} \mathrm{N}$, $20^{\circ} \mathrm{W}$, the carbonate ion concentration derived from the GLODAP dataset (together with temperature and salinity taken from Levitus climatologies) is about $170 \mu \mathrm{mol} \mathrm{kg}^{-1}$, and the calcite saturation state is about 4. Two stations close to OWS M were sampled in July 1981 during the Transient Tracers in the Ocean, North Atlantic Study (TTO-NAS) cruise programme, giving rise to carbonate ion concentration $=\sim 178 \mu \mathrm{mol} \mathrm{kg}^{-1}$ and $\Omega_{\mathrm{cal}}=\sim 4.3$ at $\sim 65^{\circ} \mathrm{N}$, $06^{\circ} \mathrm{W}$, and carbonate ion concentration $=\sim 172 \mu \mathrm{mol} \mathrm{kg}^{-1}$ and $\Omega_{\text {cal }}=\sim 4.2$ at $\sim 68^{\circ} \mathrm{N}, 03^{\circ} \mathrm{W}$ (Brewer et al, 1986, applying the revisions to the data recommended by Tanhua $\&$ Wallace, 2005).

The OCCAM (Ocean Circulation and Climate Advanced Monitoring) model output for calcite saturation state gives, for the OWS M location, an annual range in calcite saturation state from $\sim 3$ in winter to between 4 and 5 in summer (Yool, A., personal communication, 2007), in reasonable agreement with our data and model,

We also took two published datasets of $\mathrm{C}_{\mathrm{T}}, \mathrm{pCO}_{2(\mathrm{aq})}$, $\mathrm{SST}$ and salinity (Table 2 of Takahashi et al., 1985), one from north and one from south of Iceland, and used them to calculate the seasonal cycles of carbonate ion and saturation state (Fig. 13). Both stations exhibit seasonal oscillation in carbonate ion concentration and saturation state, again with higher values in summer $\left(\sim 190 \mu \mathrm{mol} \mathrm{kg}^{-1}\right.$ and $4.5-$ 5 respectively) and lower in winter $\left(110-130 \mu \mathrm{mol} \mathrm{kg}^{-1}\right.$, $\sim 3$ ). The seasonal pattern is again in reasonable quantitative agreement with this study, although the seasonal amplitude appears to be more pronounced near Iceland.
5.3.4 Could carbonate system seasonality control coccolithophore success?

It is well known that high-latitude blooms of the coccolithophore Emiliania huxleyi tend to occur in summer months (Table 2). That is to say, they follow rather than precede the typically diatom-dominated spring blooms that occur in these locations. This is true in different regions of the North Atlantic, in the Bering Sea adjacent to the North Pacific, and on the Patagonian Shelf in the southern hemisphere (Table 2). The results of our study confirm that carbonate ion concentration and $\mathrm{CaCO}_{3}$ saturation state rise rapidly in spring and stay high throughout the summer. E. huxleyi blooms therefore occur at a time of year when carbonate ion concentration and $\mathrm{CaCO}_{3}$ saturation state naturally have their highest values (Merico et al., 2006).

Of course this temporal association does not prove that the timing of E. huxleyi blooms is controlled by the seasonality of the carbonate system. Many other environmental parameters (e.g. nutrients and light) change with time of year and the seasonal variations in one or more of those other parameters could be the main driving factor. A mesocosm study has also shown that coccolithophores are able to bloom in a variety of carbonate conditions (Delille et al., 2005). Nevertheless, many experimental studies have shown a reduced rate of calcification (which presumably must affect overall fitness) by coccolithophores at low carbonate ion concentration and $\mathrm{CaCO}_{3}$ saturation state (e.g. Riebesell et al., 2000; Zondervan et al., 2002; Feng et al., 2008; although see also Langer et al., 2006 and Iglesias-Rodriguez et al., 2008). The debate still goes on as to how these organisms are affected by different growth conditions. We agree with others (e.g. Langer et al., 2006) that while carbonate ion is likely to be an important factor in contributing to necessary conditions for a healthy coccolithophore bloom, it is not likely to be the only factor.

\section{Conclusions}

Our results from a coupled carbon-ecosystem model combined with observational data from an ocean weather station in the Norwegian Sea agree with previous model-based suggestions from the eastern Bering Sea (Merico et al., 2006) about the nature of the seasonal cycles of carbonate ion concentration and $\mathrm{CaCO}_{3}$ saturation state in high-latitude seas. The Norwegian Sea data show evidence that the calcite saturation state increases after (and as a result of) the spring bloom, with higher saturation states in summer than in winter. This has already been proposed by Merico et al. (2006) from model results, and is here confirmed with data. When combined with the known prevalence of coccolithophore blooms in summer months, this provides additional evidence of a temporal association between phytoplankton and the 
carbonate system, which could possibly occur because coccolithophore success is related to the calcite saturation state.

Unlike the model, the data show that silicate is not rapidly exhausted by diatoms during the spring bloom, in contrast to the typical dynamics elsewhere; the data also highlight the possibility that grazing and macro-nutrient dynamics are not alone in controlling the observed nutrient and chlorophyll concentrations at OWS M, suggesting that there may be partial iron limitation. This is in agreement with recent work revealing that other ocean regions, such as the North Atlantic, are influenced by iron availability (Moore et al., 2006).

Acknowledgements. HF acknowledges funding from a NERC Masters studentship. This work was partly funded by the Geophysical Institute (University of Bergen), the Bjerknes Centre for Climate Research, the European Commission through the 6th Framework Programme (EU FP6 CARBOOCEAN IP, Contract no. 511176), and the Norwegian Research Council through the CABANERA (project number: 155936/700). The authors would also like to thank A. Yool for OCCAM model comparisons and F. Rey for comments on the nutrient and chlorophyll dynamics.

Edited by: U. Riebesell

\section{References}

Aguilar-Islas, A. M., Hurst, M. P., Buck, K. N., Sohst, B., Smith, G. J., Lohan, M. C., and Bruland, K. W.: Micro- and macronutrients in the southeastern Bering Sea: Insight into iron-replete and irondepleted regimes, Prog. in Ocean., 73, 99-126, 2007.

Allen, J. T., Brown, L., Sanders, R., et al.: Diatom carbon export enhanced by silicate upwelling in the northeast Atlantic, Nature, 437, 728-732, 2005.

Anderson, L. A. and Sarmiento, J. L.: Redfield ratios of remineraliszation determined by nutrient data-analysis, Global Biogeochem. Cy., 8, 65-80, 1994.

Anderson, L. G., Drange, H., Chierici, M., Fransson, A., Johannessen, T., Skjelvan, I., and Rey, F.: Annual carbon fluxes in the upper Greenland Sea based on measurements and a box-model approach, Tellus, 52B, 1013-1024, 2000.

Anderson, T. R.: Plankton functional type modelling: running before we can walk? J. Plankton Res., 27, 1073-1081, 2005.

Andruleit, H.: Coccolithophore fluxes in the Norwegian-Greenland Sea: seasonality and assemblage alterations, Mar. Micropaleo., 31, 45-64, 1997.

Andruleit, H.: Dissolution-affected coccolithophore fluxes in the central Greenland Sea (1994/1995), Deep-Sea Res. II, 47, 17191742, 2000.

Baumann, K.-H., Andruleit, H. A., and Samtleben, C.: Coccolithophores in the Nordic Seas: comparison of living communities with surface sediment assemblages, Deep-Sea Res. II, 47, 17431772, 2000.

Bellerby, R. G. J., Olsen, A., Furevik, T., and Anderson, L. G.: Response of the surface ocean $\mathrm{CO}_{2}$ system in the Nordic Seas and Northern North Atlantic to Climate Change, Geophys. Mono. Ser., 158, 189-198, 2005.
Boss, E., Perry, M. J., Swift, D., Taylor, L., Brickely, P., Zaneveld, J. R. V., and Riser, S.: Three years of ocean data from a bio-optical profiling float, EOS, Transactions of the American Geophysical Union, 89, 209-210, 2008.

Boyd, P. B., Wong, C. S., Merrill, J., Whitney, F,. Snow, J., Harrison, P. J., and Gower, J.: Atmospheric iron supply and enhanced vertical carbon flux in the NE subarctic Pacific: Is there a connection?, Global Biogeochem. Cy., 12, 429-441, 1998.

Brewer, P. G., Takahashi, T., and William, R. T.: Transient Tracers in the Oceans (TTO) - Hydrographic data and carbon dioxide systems with revised carbon chemistry data, NDP-004/R1, Carbon Dioxide Information Center, Oak Ridge National Laboratory, Oak Ridge, Tennessee, 1986.

Brostrom, G.: A note on the $\mathrm{C} / \mathrm{N}$ and $\mathrm{C} / \mathrm{P}$ ratio of the biological production in the Nordic Seas, Tellus, 50B, 93-109, 1998.

Brown, C. W. and Yoder, J. A.: Coccolithophorid blooms in the global ocean. J. Geophys. Res., 99, 7467-7482, 1994a.

Brown, C. W. and Yoder, J. A.: Distribution patterns of coccolithophorid blooms in the western North Atlantic Ocean, Cont. Shelf. Res., 14, 175-197, 1994b.

Burkhill, P. H., Leakey, R. J. G., Owens, N. J. P., and Mantoura R. F. C.: Synechococcus and its imortnace to the microbial foodweb of the northwestern Indian Ocean, Deep-Sea Res. II, 40, 773-382, 1993.

Calbet, A. and Landry, M. R.: Phytoplankton growth, microzooplankton grazing, and carbon cycling in marine systems, Limn. and Ocean., 49, 51-57, 2004.

Cloern, J. E., Grenz, C., and Vidergar-Lucas, L.: An empirical model of phytoplankton chlorophyll: carbon ratio - the conversion factor between productivity and growth rate, Lim. and Ocean., 40, 1313-1321, 1995.

Dale, T., Rey, F., and Heimdal, B.R.: Seasonal developments of phytoplankton at a high latitude oceanic site, Sarsia, 84, 419435, 1999.

Dale, T., Kaartvedt, S., Ellertsen, B., and Amundsen, R.: Largescale oceanic distribution and population structure of Calanus finmarchicus in relation to physical food and predators, Mar. Bio., 139, 561-574, 2001.

Delille, B. Harley, J., Zondervan, I., Jacquet, S., Chou, L., Wollast, R., Bellerby, R. G. J., Frankignoulle, M., Borges, A. V., Riebesell, U., and Gattuso, J.-P.: Response of primary production and calcification to changes of $p \mathrm{CO}_{2}$ during experimental blooms of the coccolithophorid Emiliania huxleyi, Gobal Biogeochem. Cycles, 19, GB2023, doi:10.1029/2004GB002318, 2005

Egge, J. K. and Aksnes, D. L.: Silicate as regulating nutrient in phytoplankton competition, MEPS, 83, 281-289, 1992.

Eppley, R. W.: Temperature and phytoplankton growth in the sea, Fishery Bull., 70, 1063-1085, 1972.

Evans, G. T., and Parslow, J. S.: A model of annual plankton cycles, Bio. Ocean., 3, 327-247, 1985.

Falck, E. and Anderson, L. G.: The dynamics of the carbon cycle in the surface water of the Norwegian Sea, Mar. Chem., 94, 43-53, 2005.

Fasham, M. J. R., Ducklow, H. W., and McKelvie, S. M.: A nitrogen-based model of plankton dynamics in the oceanic mixed layer, J. Mar. Res., 48, 591-639, 1990.

Fasham, M. J. R.: Modelling marine biota, in: The Global Carbon Cycle, edited by: Heimann, M., Springer-Verlag, Heidelberg, 457-504, 1993. 
Fasham, M. J. R., Balino, B. M., and Bowles, M. C.: Joint Ocean Global Flux Study (JGOFS), AMBIO, Special Report, 10, 4-31, 2001.

Feng, Y., Warner, M. E., Zhang, Y., Sun, J., Fu, F. X., Rose, J. M., and Hutchins, D. A.: Interactive effects of increased $p \mathrm{CO}_{2}$, temperature and irradiance on the marine coccolithophore Emiliania huxleyi (Prymnesiophyceae), Eur. J. Phycol., 43, 87-98, 2008.

Friis, K., Körtzinger A., and Wallace, D.W.R.: The salinity normalization of marine inorganic carbon chemistry data, Geophys. Res. Lett., 20, 1085, doi:10.1029/2002GL015898, 2003.

Gaard, E.: Seasonal abundance and development of Calanus finmarchicus in relation to phytoplankton and hydrography on the Faroe Shelf, ICES J. Mar. Sci., 57, 1605-1611, 2000.

Garcon, V. C., Thomas, F., Wong, C. S., and Minster, J.-F.: Gaining insight into the seasonal variability of $\mathrm{CO}_{2}$ at Ocean Station $\mathrm{P}$ using an upper ocean model, Deep-Sea Res., 39, 921-938, 1992.

Gislefoss, J. S., Nydal, R., Slagstad, D., Sonninen, E., and Holme, K.: Carbon time series in the Norwegian Sea, Deep-Sea Res. I, 45, 433-460, 1998.

Halvorsen, E., Tande, K. S., Edvardsen, A., Slagstad, D., and Pedersen, O. P.: Habitat selection of overwintering Calanus finmarchicus in the NE Norwegian Sea and shelf waters of Northern Norway in 2000-2002, Fisheries Ocean., 12, 339-351, 2003.

Haupt, O. J., Wolf, U., and Von Bodungen, B.: Modelling the pelagic nitrogen cycle and vertical particle flux in the Norwegian Sea, J. Mar. Sys., 19, 173-199, 1999.

Henson, S. A., Sanders, R., Allen, J. T. Robinson, I. S., and Brown, L.: Seasonal constraints on the estimation of new production from space using temperature-nitrate relationships, Geophys. Res. Lett., 30, 1912, doi:10.1029/2003GL017982, 2003.

Holligan, P. M., Fernandez, E., Aiken, J., Balch, W. M., Boyd, P., Burkhill, P. H., Finch, M., Groom, S. B., Malin, G., Muller, K., Purdie, D. A., Robinson, C., Trees, C. C., Turner, S. M., and Van der Wal, P.: A biogeochemical study of coccolithophore, Emiliania huxleyi, in the North Atlantic, Glob. Biogeochem. Cy., 7, 879-900, 1993a.

Holligan, P. M., Groom, S. B., and Harbour, D. S.: What controls the distribution of the coccolithophore, Emiliania huxleyi, in the North Sea?, Fisheries Oceanog., 2, 175-183, 1993b.

Kahler, P. and Koeve, W.: Marine dissolved organis matter: can its C:N ratio explain carbon overconsumption?, Deep-Sea Res. I, 48, 49-62, 2001.

Key, R. M., Kozyr, A., Sabine, C. L., Wanninkhof, R., Bullister, J. L., Feely, R. A., Millero, F. J., Mordy, C., and Peng, T. H.: A global ocean carbon climatology: Results from Global Data Analysis Project (GLODAP), Global Biogeochem. Cy., 18, GB4031, 2004.

Kohly, A.: Diatom flux and species composition in the Greenland Sea and the Norwegian Sea in 1991-1992, Mar. Geol., 145, 293 312, 1998.

Körtzinger, A., Koeve, W., Kahler, P., and Mintrop, L.: C:N ratios in the mixed layer during the productive season in the northeast Atlantic Ocean, Deep-Sea Res. I, 48, 661-688, 2001.

Langer, H., Geisen, M., Baumann, K.-H., Klas, J., Riebesell, U., Thoms, S., and Yonge, J. R.: Species-specific responseses of calcifying alga to changing seawater carbonate chemistry, Geochem. Geophys. Geosys., 7, Q09006, doi: 10.1029/2005GC001227, 2006.
Larsson, U., Hajdu, S., Walve, J., and Elmgren, R.: Baltic Sea nitrogen fixation estimated from the summer increase in upper mixed layer total nitrogen, Limnol. Oceanogr., 46, 811-820, 2001.

Merico, A., Tyrrell, T., Lessard, E. J., Oguz, T., Stabeno, P. J., Zeeman, S. I., and Whitledge, T. E.: Modelling phytoplankton sucession on the Bering Sea shelf: role of climate influences and trophic interactions in generating Emiliania huxleyi blooms in 1997-2000, Deep-Sea Res. I, 51, 1803-1826, 2004.

Merico, A., Tyrrell, T., and Cokacar, T.: Is there any relationship between phytoplankton seasonal dynamics and the carbonate system?, J. Mar. Sys., 59(1-2), 120-142, 2006.

Miller, L.A., Chierici, M., Johannessen, T., Noji, T.T., Rey, F., and Skjelvan, I.: Seasonal dissolved inorganic carbon variations in the Greenland Sea and implications for atmospheric $\mathrm{CO}_{2}$ exchange, Deep-Sea Res. II, 46, 1472-1496, 1999.

Millero, F. J., Lee, K., and Roche, M.: Distribution of alkalinity in the surface waters of the major oceans, Mar. Chem., 45, 111-130, 1998.

Moore, C. M., Mills, M. M., Milne, A., Langlois, R., Achterberg, E. P., Lochte, K., Eider, R. J. G., and La Roche, J.: Iron limits primary productivity during spring bloom development in the central North Atlantic, Glob. Change Bio., 12, 626-634, 2006.

Murata, A.: Increased surface water $p \mathrm{CO}_{2}$ in the eastern Bering Sea shelf: An effect of blooms of coccolithophorid Emiliania huxleyi?, Global Biogeochem. Cy., 20, GB4006, 1-9, 2006.

Najjar, R. G.: Marine Biogeochemistry, in: Climate System Modelling, edited by: Trenberth, K. E., Cambridge University Press, Cambridge, 241-280, 1992.

Nejstgaard, J. C., Hygum, B. H., Naustvoll, L. J., and Bamstedt, U.: Zooplankton growth, diet and reproductive success compared in simultaneous diatom- and flagellate-microzooplanktondominated plankton blooms, Mar. Ecol. Prog. Ser., 221, 77-91, 2001.

Nilsen, J. E. O. and Falck, E.: Variations in mixed layer properties in the Norwegian Sea for the period 1948-1999, Prog. in Ocean., 70, 58-90, 2006.

Nondal, G., Bellerby, R. G. J., Olsen, A., Johannessen, T., and Olafsson, J.: Predicting the surface ocean $\mathrm{CO}_{2}$ system in the northern North Atlantic: Implications for the use of Voluntary Observing Ships, Limnol. Oceanogr.. submitted, 2008.

Oliver, K. I. C. and Heywood, K. J.: Head and freshwater fluxes through the Nordic Seas, J. Phys. Ocean., 33, 1009-1026, 2003.

Orvik, K. A. and Skagseth, O.: The impact of the wind stress curl in the North Atlantic on the Atlantic inflow to the Norwegian Sea toward the Arctic, Geophys. Res. Lett., 30(17), p. 1884, 2003.

Orr, J. C., Fabry, V. J., Aumont, O., et al.: Anthropogenic ocean acidification over the twenty-first century and its impact on calcifying organisms, Nature, 437, 681-686, 2005.

Peng, T. H., Takahashi, T., Broecker, W. S., and Olafsson, J.: Seasonal variability of carbon dioxide, nutrients and oxygen in the northern North Atlantic surface water: observations and a model, Tellus, 39B, 439-458, 1987.

Peinert, R., Bodungen, B. V., and Smetacek, V. S.: Food web structure and loss rate, in: Productivity of the Ocean: Present and Past, edited by: Berger, W. H., Smetacek, V. S., and Wefer, G., John Wiley \& Sons Limited, 35-48, 1989. 
Raitsos, D. E., Lavender, S. J., Pradhan, Y., Tyrrell, T., Reid, P. C., and Edwards, M.: Coccolithophore bloom size variation in response to the regional environment of the subarctic North Atlantic. Limnol. Oceanogr., 51, 2122-2130, 2006.

Redfield, A. C., Ketchum, B. H., and Richards, F. A.: The influence of organisms on the composition of seawater, in: The Sea, edited by: Hill, M. N., Wiley, New York, 26-77, 1963.

Riebesell, U., Zondervan, I., Rost, B., Tortell, P. D., Zeebe, R. E., and Morel, F. M. M.: Reduced calcification of marine plankton in response to increase atmospheric $\mathrm{CO}_{2}$, Nature, 407, 634-637, 2000.

Robertson, J. E., Robinson, C., Turner, D. R., Holligan, P., Watson, A. J., Boyd, P., Fernandez, E., and Finch, M.: The impact of a coccolithophore bloom on oceanic carbon uptake in the northeast Atlantic during summer 1991, Deep-Sea Res. I, 41, 279-314, 1994.

Sambrotto, R. N., Savidge, G., Robinson, C., Boyd, P., Takahashi, T., Karl, D. M., Langdon, C., Chipman, D., Marra, J., and Copdispoti, L.: Elevated consumption of carbon relative to nitrogen in the surface ocean, Nature, 363, 248-250, 1993.

Skjelvan, I., Chierici, M., and Olafsson, J.: Horizontal distributions of $\mathrm{NC}_{\mathrm{T}}, \mathrm{NA}_{\mathrm{T}}$ and $\mathrm{fCO}_{2}$ in the Nordic Seas, In Carbon and Oxygen Fluxes, in: the Nordic Seas, Skjelvan, I., PhD thesis, University of Bergen, Norway, 1999.

Skjelvan, I., Olsen, A., Anderson, L. G., Bellerby, R. G. J., Falck, E., Kasajima, Y., Kivimäe, C., Omar, A., Rey, F., Olsson, A., Johannessen, T., and Heinze, C.: A review of the inorganic carbon cycle of the Nordic Seas and Barents Sea, Geophys. Mono., 158, 157-176, 2005.

Skjelvan, I., Falck, E., Rey, F., and Kringstad, S. B.: Inorganic carbon time series at Ocean Weather Station $\mathrm{M}$ in the Norwegian Sea, Biogeosciences, 5, 549-560, 2008, http://www.biogeosciences.net/5/549/2008/.

Smyth, T. J., Tyrrell, T., and Tarrant, B.: Time series of coccolithophore activity in the Barents Sea, from twenty years of satellite imagery, Geophys. Res. Lett., 31, doi:10.1029/2004GL019735, 2004.
Takahashi, T., Ólafsson, J., Broecker, W. S., Goddard, J., Chipman, D. W., and White, J.: Seasonal variability of the carbonnutrient chemistry in the ocean areas west and north of Iceland, Rit Fiskideildar, 9, 20-36, 1985.

Takahashi, T., Ólafsson, J., Goddard, J. G., Chipman, D. W., and Sutherland, S. C.: Seasonal variability of $\mathrm{CO}_{2}$ and nutrients in the high-latitude surface oceans: a comparative study, Glob. Biogeochem. Cy., 7, 843-878, 1993.

Tanhua, T. and Wallace D. W. R.: Consistency of TTO-NAS Inorganic Carbon Data with modern measurements, Geophys. Res. Lett., 32, L14618, doi:10.1029/2005G:032348, 2005.

Taylor, A. H., Harbour, D. S., Harris, R. P., Burkhill, P. H., and Edwards, E. S.: Seasonal succession in the pelagic ecosystem of the North Atlantic and the utilization of nitrogen, J. Plank. Res., 15, 875-891, 1993.

Taylor, K. E.: Summarizing multiple aspects of model performance in a single diagram, J. Geophys. Res.-Atmos., 106 (D7), 71837192, 2001.

Tyrrell, T., Hollligan, P. M., and Mobley, C. D.: Optical impacts of oceanic coccolithophore blooms, J. Geophys. Res.-Oceans, 104(C2), 3223-3241, 1999.

Tyrrell, T. and Merico, A.: Emiliania huxleyi: bloom observations and the conditions that induce them, in: Coccolithophores, From Molecular Processes to Global Impact, edited by: Thierstein, H. R. and Young, J. R., Springer, Berlin, 75-97, 2004.

Tyrrell, T., Merico, A., Waniek, J., Wong, C. S., Metzl, N., and Whitney, F.: Effect of seafloor depth on phytoplankton blooms in high-nitrate, low-chlorophyll (HNLC) regions, J. Geophys. Res.Biogeosci., 110, G02007, 2005.

Zondervan, I., Rost, B., and Riebesell, U.: Effect of $\mathrm{CO}_{2}$ concentration on the PIC/POC ratio in the coccolithophore Emiliania huxleyi grown under light-limiting conditions and different daylengths, J. Exp. Mar. Biol. Ecol., 272, 55-70, 2002. 